\title{
Responding to a Shadow Banking Crisis: The Lessons of 1763
}

\author{
Stephen Quinn and William Roberds
}

\author{
Working Paper 2012-8 \\ June 2012
}

\begin{abstract}
In August 1763, northern Europe experienced a financial crisis with numerous parallels to the 2008 Lehman Brothers episode. The 1763 crisis was sparked by the failure of a major provider of acceptance loans, a form of securitized credit resembling modern asset-backed commercial paper. The central bank at the hub of the crisis, the Bank of Amsterdam, responded by broadening the range of acceptable collateral for its repo transactions. Analysis of archival data shows that this emergency source of liquidity helped to contain the effects of the crisis, by preventing the collapse of at least two other major securitizers. While the underlying themes seem to have changed little in 250 years, the modest scope of the 1763 liquidity intervention, together with the lightly regulated nature of the eighteenth century financial landscape, provide some informative contrasts with events of late 2008.
\end{abstract}

JEL classification: E58, G01, G21, N21

Key words: shadow banks, central banks, liquidity

The authors thank Christiaan van Bochove for making them aware of the Malinowski (2011) dataset. Helpful comments on earlier drafts were provided by Roger Farmer, Rod Garratt, Peter Koudijs, Rob Reed, Ellis Tallman, François Velde, Larry Wall, and participants in seminars at the Atlanta Fed, De Nederlandsche Bank, and the University of Utrecht. Christina Hartlage provided research assistance. The views expressed here are the authors' and not necessarily those of the Federal Reserve Bank of Atlanta or the Federal Reserve System. Any remaining errors are the authors' responsibility.

Please address questions regarding content to Stephen Quinn, Department of Economics, Texas Christian University, Box 298510, 2855 Main Drive, Fort Worth, Texas 76129, 817.257.6234, s.quinn@tcu.edu, or William Roberds, Research Department, Federal Reserve Bank of Atlanta, 1000 Peachtree Street, N.E., Atlanta, Georgia 30309-4470,404-498-8970, william.roberds@atl.frb.org.

Federal Reserve Bank of Atlanta working papers, including revised versions, are available on the Atlanta Fed's website at frbatlanta.org/pubs/WP/. Use the WebScriber Service at frbatlanta.org to receive e-mail notifications about new papers. 


\section{Responding to a Shadow Banking Crisis: the Lessons of 1763}

\section{Introduction}

The 2008 Lehman crisis was notable as a banking panic where the liquidity of bank deposits was rarely called into question. In place of bank runs, the crisis was manifested as the dysfunction of certain securities markets. Many of the affected securities were the products of the shadow banking sector, a lightly regulated group of nonbank institutions (Pozsar et al. 2010) that had previously been able to manufacture financial claims with bank-deposit-like liquidity and "information-insensitivity” (Dang et al. 2009).

Another remarkable feature of the 2008 crisis was the scope of the resultant policy response. In an effort to prevent a worldwide financial meltdown, central banks expanded their balance sheets to record multiples of their pre-crisis size (see Allen and Moessner 2011 for a scorecard). Public-sector liquidity also flowed to unexpected places, to shadow banks outside the traditional regulatory safety net, and across national borders through the aggressive use of central bank swap lines (Allen and Moessner 2010, Goldberg et al. 2010).

The extraordinary nature of the Lehman crisis naturally leads to a number of questions. Would a different pre-crisis regulatory environment have increased market resiliency (e.g., Acharya et al. 2010, Gorton and Metrick 2010)? What if governments and central banks had displayed a lesser response to the Lehman failure (e.g. McAndrews et al. 2008, Adrian et al. 2010, Fleming et al. 2010)? To help answer these "what ifs," this paper goes to the Amsterdam Crisis of 1763 to find a shadow banking precedent. In doing so, we follow Schnabel and Shin (2004) by drawing parallels between pre-Napoleonic Continental banking institutions, and the financial market structures of today.

Why late eighteenth-century Amsterdam? It was replete with merchant banks offering securitization. To enhance the credit and liquidity of debt instruments, the Dutch substituted a borrower's obligation with a debt guaranteed by a merchant bank. The borrowers were located all over the European trading world, but the credit hub was Amsterdam, so credit risk was concentrated there. The typical Dutch merchant bank financed itself by issuing debt before the original borrowers were paid, following a business model comparable to modern asset-backed commercial 
paper (ABCP) conduits. Merchant banks’ dependence on debt rollover made Amsterdam in 1763 as vulnerable to aggregate shocks as New York was in 2008.

The spark for the 1763 crisis was the Lehman-like failure of the banking house Gebroeders de Neufville. As occurred in 2008, de Neufville's failure made creditors reluctant to purchase new debt from surviving banks that were thought to be following a similar market strategy. Our investigations indicate that the resulting shadow run may have been greater (relative to the size of the market) than that experienced in 2008. To measure the run, we have reconstructed the weekly flow of funds into and out of accounts maintained by the eight largest merchant banks at the Bank of Amsterdam (also the Bank). Large merchant banks were often obliged to use the Bank to settle their debts, called bills of exchange, but light regulation otherwise meant that the Dutch banks did not hide their trading activity. Rich archival data and straightforward financial architecture allow us to reconstruct the portion of the panic that occurred through the Bank's accounts.

A second parallel is in the Bank of Amsterdam's response to the crisis. As in 2008, access to central bank liquidity was expanded in an unprecedented and ad hoc basis. Differently, this expansion was relatively narrow in scope. The policy intervention worked through the Bank's repo facilities to broaden the set of assets eligible for repo to include silver bullion. Liquidity also expanded via the traditional channel of repo transactions with trade coins.

To give a comparative overview, Figure 1 plots the expansion of the Bank of Amsterdam's balance sheet in 1763 to the Federal Reserve’s in 2008-9. In each case, the balance sheets are scaled to the start of the crisis and broken down by asset class. For the Federal Reserve, the breakdown is between traditional assets (treasuries and discounts), non-bank lending programs and other new programs like the AIG bailout, mortgage backed security purchases and liquidity swaps with foreign central banks. Figure 1 also plots assets of the Bank of Amsterdam acquired by traditional channels and by its ad hoc bullion window. The Bank of Amsterdam's bullion window and its traditional response were comparable in timing, but more modest in scale than the analogous elements of the Fed's expansion. The aggregate increase in Dutch liquidity was a “mere” 40 percent over six months, perhaps more impressive when one considers that the Bank did not operate a traditional discount window or engage in transactions with other central banks. 
Figure 1. Weekly Central Bank Assets in 1763 and 2008

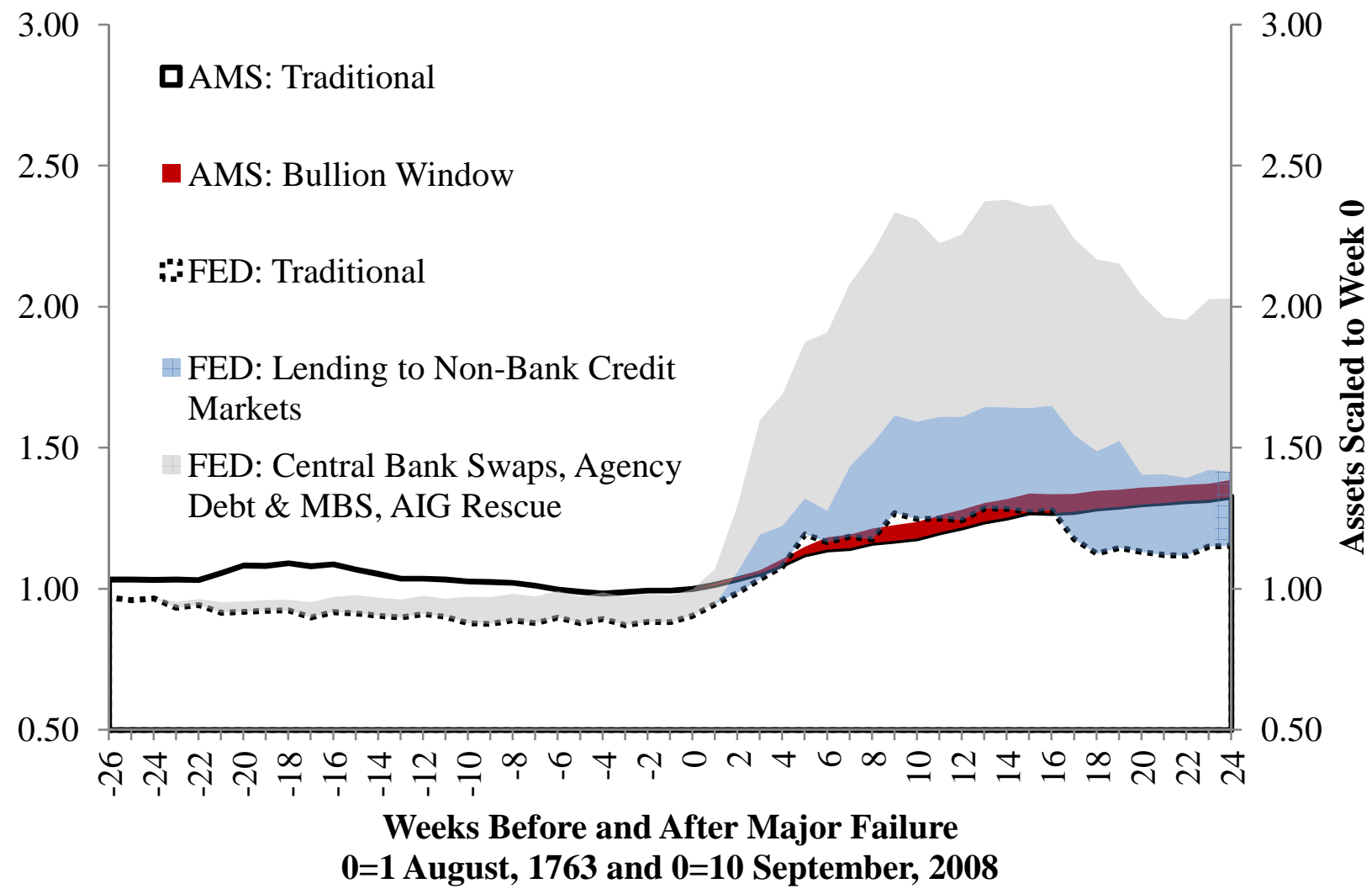

Sources: Federal Reserve and Stadsarchief Amsterdam 5077.

The bullion window accounts for a relatively small proportion of the Bank's post-crisis balance sheet, but the micro evidence shows that this liquidity channel had disproportionately large effects. Our new data set tracks liquidity creation by bank, and examination of this data shows that the bullion window likely prevented the failure of at least two additional large merchant banks. In this way, the Bank's policies avoided further major failures within Amsterdam and avoided too-big-to-fail bailouts. The costs of the Bank's minimalist approach, however, were disproportionately felt in Amsterdam's satellite markets (Berlin, Hamburg, Stockholm, etc.) which experienced an almost complete shutoff of credit flows.

As a precedent, the Crisis of 1763 confirms the model of a shadow bank as a financial firm that has to roll over its financing before the backing assets mature. Shadow runs are the sudden inability to sell new debt, as arrangements designed to make claims money-like fail. The history 
opens potential explanations for the ascent of modern shadow banking, for the Dutch system evolved in response to demand for securitization rather than to avoid regulation. Finally, the story shows how a shadow run was alleviated—if only partially—-through aggressive repurchase facilities but without explicit bailouts or too-big-to-fail guarantees.

The rest of this paper is organized as follows. Section 2 reviews related literature. Section 3 discusses banking institutions in eighteenth century Amsterdam. Section 4 discusses the collateral shocks that preceded the crisis and its outbreak. Section 5 presents empirical evidence on the severity of the crisis, and section 6 analyzes policy responses. A final section concludes.

\section{Related literature}

There is rich historical literature on the Panic of 1763, with contributions by Büsch (1797), Soetbeer (1855), Sautijn Kluit (1865), van Dillen (1922, 1931), Skalweit (1937), Henderson (1962), and Spooner (2002), among others. The analysis below relies on these works, and especially on the monograph of de Jong-Keesing (1939), both for historical narrative and as guides to primary sources.

The historical literature is synthesized by Schnabel and Shin (2004), who also propose a theoretical model of contagion effects stemming from de Neufville’s failure. Our analysis complements theirs, in that we measure how the panic hit other banks and how the Bank of Amsterdam's response was able to limit the outbreak of contagion within the Amsterdam market.

Flandreau and Ugolini (2011) investigate a similar crisis and response story for London in 1866. In England, the failure of a large bank caused shadow banks (called bill brokers) to suddenly become unable to finance international acceptance credit. The Bank of England responded by rapidly expanding liquidity (Flandreau and Ugolini 2011, 36-7). Unlike Amsterdam, however, the English banks did not necessarily settle bills at their central bank, so the Bank of England accounts did not double as conduits. In Amsterdam, we are able to reconstruct both lender of last resort funding and the obligations pressing on shadow banks. 


\section{Shadow banking in 1763}

Financial activity in late-eighteenth century Amsterdam was dominated by a group of merchant banking firms. In contemporary parlance, these firms were known simply as bankers (banquiers) (de Jong-Keesing 1939, 69). Bankers were proprietary firms that dealt in trade goods and that also provided financing to other merchants. These firms were not deposit banks in the English tradition; deposit-taking was viewed as an excessively risky, downmarket source of funding. Aversion to deposits was famously crystallized in a clause of the partnership contracts of Amsterdam's most prominent bank, Hope en Compagnie: "the business of this firm will be restricted to matters of commerce and commissions, and it will not engage in negotiations relating to deposited funds, or similar transactions” (de Jong-Keesing 1939, 69; Buist 1974, 37).

Since deposits were scarce, financial intermediation was accomplished through a securitization scheme known as the acceptance loan (acceptcrediet). The building block of the acceptance loan was an instrument known as the bill of exchange. Somewhat resembling a modern check, a bill of exchange transaction involved a minimum of three actors: a drawer, a drawee, and a beneficiary (see e.g., Schnabel and Shin 2004, 935-939). The bill would be created by the drawer, who would instruct the drawee to pay the beneficiary a certain sum, at a fixed place, at some future date. The drawee would indicate his intention to pay the bill by signing or "accepting” it. A beneficiary could also transfer the bill to a fourth party by endorsing it over.

\subsection{Acceptance loans and conduits}

In an acceptance loan transaction, the lender was the drawee of a bill, typically a merchant banker in a prominent commercial city such as Amsterdam. To make the arrangement work, the banker had to "close the loop” of obligations created by the drawing of a bill, i.e., to somehow arrange for repayment. Table 2 below presents a stylized example of one common technique for constructing an acceptance loan.

For ease of comparison, consider first the interaction of four agents in the context of a modern, ABCP type of arrangement (see, e.g., Brunnermeier 2009, Acharya, Suarez, and Schnabl 2010, 
Kaperczyk and Schnabl 2010). There are three periods: 0, 1, and 2. Agent $D$ is a debtor who borrows for two periods, $C 1$ is a creditor who lends early, $C 2$ is a creditor who lends late, and $B$ is a banker-conduit who creates secondary debt and provides credit/liquidity enhancement. ${ }^{1}$ Table 1 presents a stylized version of $A B C P$, in which debt issued by $B$ is "backed" by cash flows from the activities of $D$.

Table 1: stylized ABCP conduit, 2008

$\begin{array}{ll}\text { Period 0: } & \begin{array}{l}\text { (a) } D \text { creates and sells an ASSET to } B \\ \text { (b) } B \text { creates and sells ABCP1 to } C 1\end{array} \\ \text { Period 1: } & \begin{array}{l}\text { (a) } B \text { creates and sells ABCP2 to } C 2 \\ \text { (b) } B \text { repays } C 1 \text { for ABCP1 }\end{array} \\ \text { Period 2: } & \begin{array}{l}\text { (a) } D \text { repays } B \text { for ASSET } \\ \text { (b) } B \text { repays } C 2 \text { for APCP2 }\end{array}\end{array}$

A key feature of the story, and the source of $B$ 's profit, is that the ABCP issued by $B$ has credit and liquidity guarantees that make it into a palatable investment for $C 1$ and $C 2$. As became clear in 2007-2008, however, $B$ 's guarantee to $C 1$ may depend on rollover funding from C2 (Period 1(a) in Table 1), which may be impaired in the wake of extreme market events (see, e.g., Kaperczyk and Schnabl 2010).

Let us now consider how rollovers funded securitization in Amsterdam in 1763 (to do so we need an extra period and a second location). In this example, $D$ would typically be a merchant operating in a remote market (e.g., Hamburg) and $B$ would be an Amsterdam banker. $C 1$ and $C 2$ are bill investors, residing in Hamburg and Amsterdam respectively, in this stylized example. An acceptance loan from $B$ is used to "securitize" a profitable activity by $D .^{2}$

\footnotetext{
${ }^{1}$ In practice a conduit is legally distinct from its sponsoring bank; the two are merged for purposes of this introductory example.

${ }^{2}$ Traditionally, an acceptance loan was (implicitly, though not formally) secured by commodity shipments in the opposite direction of the bill obligation. The link between bills and goods became obscured during the credit boom leading up to the Neufville crisis, however, as bills were increasingly used for simple speculation on exchange rate movements or commodity prices.
} 


\section{Table 2: stylized acceptance loan, 1763}

In Hamburg

$\begin{array}{ll}\text { Period 0: } & \text { (a) } D \text { draws BILL1 on } B \\ & \text { (b) } D \text { sells it to } C 1 \\ & C 1 \text { travels to Amsterdam }\end{array}$

Period 1:

Period 2: $\quad$ (a) D accepts BILL2

Period 3: $\quad$ (a) $D$ settles BILL2 with $C 2$
In Amsterdam (a) $B$ accepts BILL1

(b) $B$ draws BILL2 on $D$

(c) $B$ sells BILL2 to $C 2$

C2 travels to Hamburg

(b) B settles BILL1 with $C 1$

As with the modern ABCP arrangement, credit and liquidity guarantees by $B$ play a big role. $C 1$ is willing to take a bill drawn by $D$ because he thinks it will be accepted by $B$. Similarly, $C 2$ is willing to take the bill drawn by $B$ on $D$ because he knows that $B$ is liable if $D$ cannot pay.

Also like the ABCP arrangement, the acceptance loan scheme is vulnerable to disruptions in rollover funding (Period 1(b) in Table 2): $B$ may have trouble keeping promises to $C 1$ if he cannot sell a bill to C2. Clearly, such disruptions are more prone to occur in times of aggregate shocks: if $B$ has guaranteed many borrowers such as $D$ with correlated credit risk, doubts may arise about B's ability to make good on his guarantees. As emphasized by Schnabel and Shin (2004) and many others, this funding risk can interact with market risk in a self-reinforcing cycle. Participants in need of funding liquidity may dump assets on the market, depressing prices and thereby reinforcing perceptions of increased credit risk.

In 1763, there was an additional channel for market disruption that was not present in 2007-2008 crisis. This channel arises from the contingent nature of a bill transaction: if a banker declines to accept ("protests”) the bill (Period 1(a) in Table 2), $D$ loses the funding of the bill and becomes subject to the liquidity risk of suddenly having to repay $C 1$. When bankers protest bills to conserve their own liquidity, they can force parties such as $D$ into bankruptcy, in which case a credi- 
tor such $C 1$ has (at least temporarily) lost his principal on the first trade. ${ }^{3}$ The acceptance credit (or bankers' bills) common in later Anglo-American systems either eliminated protest risk by having the bank accept the bill before the drawer sold it or reduced protest risk through instruments of provisional acceptance such as a banker's letter or a correspondent's assurance. ${ }^{4}$

Moreover, $C 1$ could not escape principal risk by selling (“discounting”) the bill. Contemporary commercial law mandated that all signatories to a bill retained liability if the drawee could not pay (Schnabel and Shin 2004, 938-939). The limited prevalence of deposit banks meant that bills sometimes circulated as money in large-value commercial transactions, especially after acceptance by a major bank. The attendant risks, stemming from the use of bills as a monetary instrument, created destructive linkages during the course of the 1763 panic. $^{5}$

\subsection{Banking and liquidity}

While virtually all merchants in eighteenth-century Amsterdam dealt in bills of exchange, most merchants' bill transactions were limited to a small group of “friends”-commercial counterparties in other cities — and even among friends, exposures were subject to strict limits. Also, the typical merchant’s bills were rarely transferred more than once after issue (de Jong-Keesing 1939, 58-65), indicating that they had limited liquidity. Our analysis of bill settlement patterns suggests that de Jong-Keesing's characterization would have been appropriate for over eighty percent of the merchants with accounts at the Bank of Amsterdam, who settled less than one bill per week on average.

The bankers provided a conspicuous exception to this pattern. Surviving records show that the most active merchants in Amsterdam dealt in thousands of bills each year (see Table A1 in Appendix A), drawn by a wide range of counterparties. When the house of de Neufville failed in

\footnotetext{
${ }^{3}$ Although $C 1$ still has recourse against $D$, it might be difficult or time-consuming for $C 1$ to collect. Principal risk could be manifested in other ways as well. Consider a scenario where $B$ (for example, Neufville) accepts BILL1 in period 1(a) but goes bankrupt before maturity of the bill in period 2. $C 1$ has again lost liquidity and $D$ is liable for the full amount of the bill. Depending on circumstances, $C 1$ could lose the entire amount of the initial trade. A modern term for this type of risk is "Herstatt risk" (Committee on Payment and Settlement Systems 2003).

${ }^{4}$ See Davis and Gallman (2001, 127-30); Ferderer (2003, 667-73); and Flandreau and Ugolini (2011, 7).

${ }^{5}$ An echo of this system can be found in the practice of rehypothecation, in which when a party borrows using collateral that has been posted ("hypothecated") by someone who that party has lent to. A chain of rehypothecations can thus support a sequence of credit transactions, in much the same way as the circulation of a bill of exchange might have done at the time of the Neufville crisis. See Singh and Aitken (2010) on rehypothecation and its role in the Lehman crisis.
} 
August 1763, its list of creditors included over 100 bill counterparties, the great majority of these residing in cities outside of the Dutch Republic (de Jong-Keesing 1939, 101-110). In many outlying areas, the only commonly available form of trade finance was to draw a bill on a banker in Amsterdam. ${ }^{6}$ Accepted bankers’ bills were widely traded in secondary markets in Amsterdam and other commercial centers.

Competitive pressures kept the number of true "bankers" low. Profit margins on bill acceptance were minuscule, usually 1/3 percent or less (Büsch 1797, 121; de Jong-Keesing 1939, 71), so profits relied on volume built on leverage. In principle, any merchant with a Bank of Amsterdam account could act as a banker; there were no legal barriers to entry or solvency requirements forcing closure. In the absence of ratings agencies or public release of financial information, however, a banker had to maintain a reputation for reliability. Failure to settle a bill could quickly destroy a merchant's reputation, and suspending payments could force a merchant into bankruptcy in matter of days. A critical requirement for bankers was therefore to maintain liquidity, and that meant an adequate balance at the Bank of Amsterdam.

The Bank of Amsterdam (the Bank) was a municipal bank that supplied book-entry settlement of bills of exchange. ${ }^{7}$ The Bank did not issue bank notes, so it is possible to track much of the bill market, for most bills drawn abroad on Amsterdam were payable through the Bank. ${ }^{8}$ At the maturity, $B$ (the drawee) discharged his obligation by transferring Bank funds to the beneficiary in the amount of the face value of the bill. ${ }^{9}$ There was no clearing house and no netting of obligations. ${ }^{10}$ Meticulous and virtually complete records of the "funds side" of these settlements are

\footnotetext{
${ }^{6}$ Most markets did have traditional systems of longer-term lending based on mortgages. See e.g. Hoffman, PostelVinay and Rosenthal (2000).

${ }^{7}$ See van Dillen (1934) and Dehing and 't Hart (1997) on the history of the Bank.

8 There was a less important market for “current money” bills-bills settled outside the bank. This market was the domain of a group of intermediaries known as cashiers, whose activities are described in section 5 below.

${ }^{9}$ In a modern context, this scheme would be classified as a delivery-versus-payment "model 1" (i.e., gross settlement against the full value of the security; see Committee on Payment and Settlement Systems 1992). The transfer of Bank funds constituted final settlement of the bill obligation.

${ }^{10}$ We note that the London Clearing House, the first deposit bank clearinghouse and prototype for many subsequent clearing organizations, was not founded until 1773 (Joslin 1954).
} 
preserved in the ledgers of the Bank of Amsterdam: the Bank’s 1763 ledgers record around 270,000 transactions (authors' rough estimate) ${ }^{11}$ in almost 2,500 accounts.

Table 3 gives the Bank's balance sheet on the eve of the crisis. Profits were generated by fees on accounts and by limited lending to the Dutch East India Company and the Province of Holland. The Bank had no long-term capital, so when the city took the previous year's profits in April, the Bank's capital became negative. The capital would recover as loan interest and transaction fees were collected later in the fiscal year.

Table 3. Bank of Amsterdam Balance Sheet, August 1, 1763, in bank florins.

\begin{tabular}{lr|lr} 
Assets & \multicolumn{2}{l}{ Liabilities } \\
Coins Under Receipt (“Repo”) & $21,606,690$ & Accounts & \\
Coins Unencumbered & 288,434 & & \\
Loans & 527,264 & Capital & $-237,757$ \\
Total & $22,422,388$ & Total & $22,422,388$
\end{tabular}

Source: Authors’ calculation.

Beyond loans, the Bank's balance sheet had two ways to create liquidity (account liabilities). The first was to accept deposits, but "deposit” is something of a misnomer, for Bank of Amsterdam deposits functioned like a modern central bank repo transaction. Someone bringing high-quality trade coins (negotiepenningen) into the bank was credited a certain amount of Bank funds based on official valuations of the coin, and he also received a receipt endowing him with the option to repurchase the same coins within a six-month period at a small cost $(1 / 4$ percent for most silver coins). ${ }^{12}$ Examination of the Bank's vault records indicates that virtually all of these redemption options were exercised, i.e., that in practice "deposits" into the Bank were term repos. The availability of repos effectively pegged the risk-free annualized short-term interest rate at slightly

\footnotetext{
${ }^{11}$ Calculated as (6,000 pages) $\times(90$ entries per page) $\div 2$ (to adjust for double-entry bookkeeping), to yield an estimate of 270,000 transactions.

${ }^{12}$ If a receipt holder chose not to exercise the repurchase option, the initial deposit was treated as a true sale. This feature of the receipt system apparently incorporates the "safe harbor" bankruptcy preference of modern repo contracts (see e.g., Gorton and Metrick 2010, 276-278).
} 
more than $1 / 2$ percent. Receipts were the only way to redeem bank money for coin, so Bank accounts had many of the characteristics of fiat money (van Dillen 1964b, Quinn and Roberds 2010). There were 22.6 million florins in accounts and 21.6 million in coins under receipt, so the bank had 1 million in accounts unencumbered by receipts.

The Bank could also create bank accounts without receipts through the direct purchase or sale of coins. The Bank did not engage in open market operations in 1763 , so the 288,434 florins in unencumbered coins were the residue of previous interventions.

We should also note that people could purchase existing Bank funds from other account holders without changing the balance sheet. This was done in an open outcry market held in front of the Bank every day in which (effectively) coin could be traded against Bank money (van Dillen 1964a). The market price was the agio, or gap, between two units of account: Bank money (the "bank" florin or guilder) versus the value of circulating money (the "current" guilder or florin). ${ }^{13}$ We will use florin to denote the bank unit of account and guilder to denote the non-bank unit of account.

The Bank’s funding “pipelines” involved the use of expensive, high-quality collateral, i.e., trade coins. The Bank of Amsterdam was a conservatively run institution that did not extend credit against bills, allow accounts to overdraft, or operate any kind of Lombard facility. ${ }^{14}$ Despite these restrictions, historical evidence shows that Amsterdam bankers were routinely able to settle bills in amounts that greatly exceeded their average balances at the Bank, without tying up much in the way of high-quality collateral. This trick required the use of creative, ABCP-conduit-like arrangements of the type illustrated in Table 2.

\footnotetext{
${ }^{13}$ During normal times, arbitrage tended to keep the agio close to official differentials between these two units of account, i.e., between 3.85 and 4.1 percent. These boundaries are for the ryxdaalder (originally called the dukaat), a silver coin that was the primary domestic coin used for repurchase agreements at the Bank (van Dillen 1925, 906; Polak 1998, 73-4).

${ }^{14}$ Accounts were not always reconciled on a daily basis, so overdrafts did occasionally occur. Also, for every year for a century, the Bank of Amsterdam had lent to a government sponsored entity the (Dutch East India Company) to finance ships sailing to Asia (van Dillen 1925, 981-3).
} 


\subsection{Evidence}

According to our simple model of eighteenth century merchant banking, a banker B's source of market funding would consist of bills drawn on debtors such as $D$. In normal times the banker could easily sell these in the Amsterdam bill market. On the other side, the liabilities of the banker would consist largely of bills drawn on and accepted by $B$, originating with this same group of debtors.

To check the applicability of our simple shadow banking model, we examined the ledger accounts of the Bank of Amsterdam. Notice in the Table 2 example, payments through the Bank's accounts would typically show up at two stages, Period 1(c) - the sale of a bill by $B$ to $C 2$-and, Period 2(b) — the settlement of the original bill drawn on $B$. The Bank's ledgers thus provide an incomplete, but still highly informative picture of the banker's activities. In particular, a merchant banker's account at the Bank represents a sort of "virtual conduit" for acceptance loans provided by the banker, recording the payments in by debtors, the payments going out to creditors, and the resultant cash balance.

An unfortunate limitation of the data is that the Bank's ledgers record no information on the "securities" side of a transaction. This means that information available in modern empirical studies of ABCP (e.g., Covitz, Liang, and Suarez 2009), such as maturity and yield of individual instruments, is lacking. This also means that the recorded transfers undoubtedly do, in some cases, represent activity other than bill transactions. ${ }^{15}$ The historical literature, however, seems to agree that the principal use of Bank accounts was for bill transactions, so we will simply assume that each recorded transaction corresponds to the transfer of a bill. A third difficulty is that there is no reliable way to tell if a payment is settlement of a bill or the purchase a bill as an investment. This distinction does not matter for many of our inferences; however, at the peak of the crisis (August-September 1763) our calculations will assume a lack of discretionary lending, so virtually all observed transactions are non-discretionary settlement, for failure to honor an accepted bill had legal consequences such as bankruptcy.

\footnotetext{
${ }^{15}$ It should be emphasized that transfers over the Bank of Amsterdam's accounts were generally "large-value” payments. In our sample, the average payment size in the bankers' accounts is about 4,000 florins, as compared to the contemporary daily wage for a laborer of approximately one florin (de Vries and van der Woude 1997).
} 
As with modern payment systems, the typical entry in the Bank's ledgers is a datum of the form

$$
X_{i j d}
$$

representing a transfer of $x$ florins from account $j$ to account $i$ on day $d$, entered as a debit under merchant $j$ 's accounts, with a corresponding credit entry for merchant $i{ }^{16}$ Each ledger page also contains an opening balance. These can be combined with the transfer data to yield a daily opening balance $b_{j d}$ for each trading day. The scope of these data, which must be hand transcribed, is a challenge. A full accounting of $x_{i j d}$ for the fiscal year 1763 (late January 1763 - early January 1764) as is available with modern systems, would yield a data vector of approximate dimension 1.5 billion (2,455 accounts $\times 2,455$ accounts $\times \sim 250$ trading days) with approximately 270,000 nonzero entries. To arrive at a dataset of manageable size, a number of simplifications were employed.

The first of these was to time-aggregate $x_{i j d}$ into weekly payment flows for 50 weeks, for the Bank was closed in January and in July to reconcile accounts. We also focus on the eight most active players in the Amsterdam bill market in the years leading up to the panic, as identified in de Jong-Keesing $(1939,120)$. Together, payments to and from these players account for about eight percent of transactions in the Bank’s ledgers in 1763, as measured by “payments volume,” i.e., by number of ledger entries. Transactions between these eight accounts and the other account holders are aggregated into the account of a fictional ninth agent ("rest of the Bank" or ROB). Finally, we employ a tenth account to keep track of coin inflows to and outflows from the first nine accounts. ${ }^{17}$ The end result of these simplifications is a data vector $\left\{X_{i j t}\right\}$ of payments between the ten accounts over weeks $t=1, \ldots, 50$, of a more tractable dimension $(10 \times 10 \times 50=$ 5000 data points). In a similar fashion, $\left\{b_{j d}\right\}$ was time-sampled to yield a weekly starting balance series $\left\{B_{j t}\right\}$.

\footnotetext{
${ }^{16}$ Unlike modern payment systems, the Bank of Amsterdam's accounts do not record the time of day when a payment is made. In fact there is often a divergence of a day between the timing of a debit entry and the corresponding credit entry, suggesting that contemporary concept of "real-time gross settlement" amounted to at best daily settlement of accounts.

${ }^{17}$ Additional accounts are necessary to track bullion deposits and withdrawals, discrepancies between debits and credits arising from missing entries, and changes in the capital position of the Bank. Details are given in appendix C.
} 
The data shows the dominance of rollover financing through the scale of payments by bankers and through the near equality of those debits with payments to bankers from the rest of the bank. Over the first half of 1763, the eight bankers had a mean weekly expenditure of 1.97 million florins and a mean weekly starting balance 1.49 million florins, so each week the bankers spent 132 percent of initially available funds. ${ }^{18}$ At the same time, non-bankers paid the bankers an average of 1.81 million florins per week, so a typical week had sales of new bills roughly equivalent to the settlement of old bills. The small difference was florins spent to withdraw coins or pay bank fees.

To see the variation within, Figure 2 reports each banker's balances and ratio of expenditures-tobalances. The data are consistent with de Jong-Keesing's (1939, 74-75) classification of Amsterdam bankers into the established, well-capitalized houses (Hope, Pels, and Clifford) and a more levered group of "parvenus" ( de Neufville, Vernede, de Smeth, Horneca Hogguer, and Cazenove) who had been able to break into the top ranks of the bankers during the credit boom of the Seven Years' War (1756-1763). The turnover in the parvenus' accounts is quite active despite having Bank balances distinctly lower than the old houses. Viewed from the perspective of its settlement accounts, Gebroeders de Neufville does not appear any riskier than similar firms.

\footnotetext{
${ }^{18}$ See Table 3 in Appendix A.
} 
Figure 2. Ratio of Banker Expenditures to Balances, January-July 1763

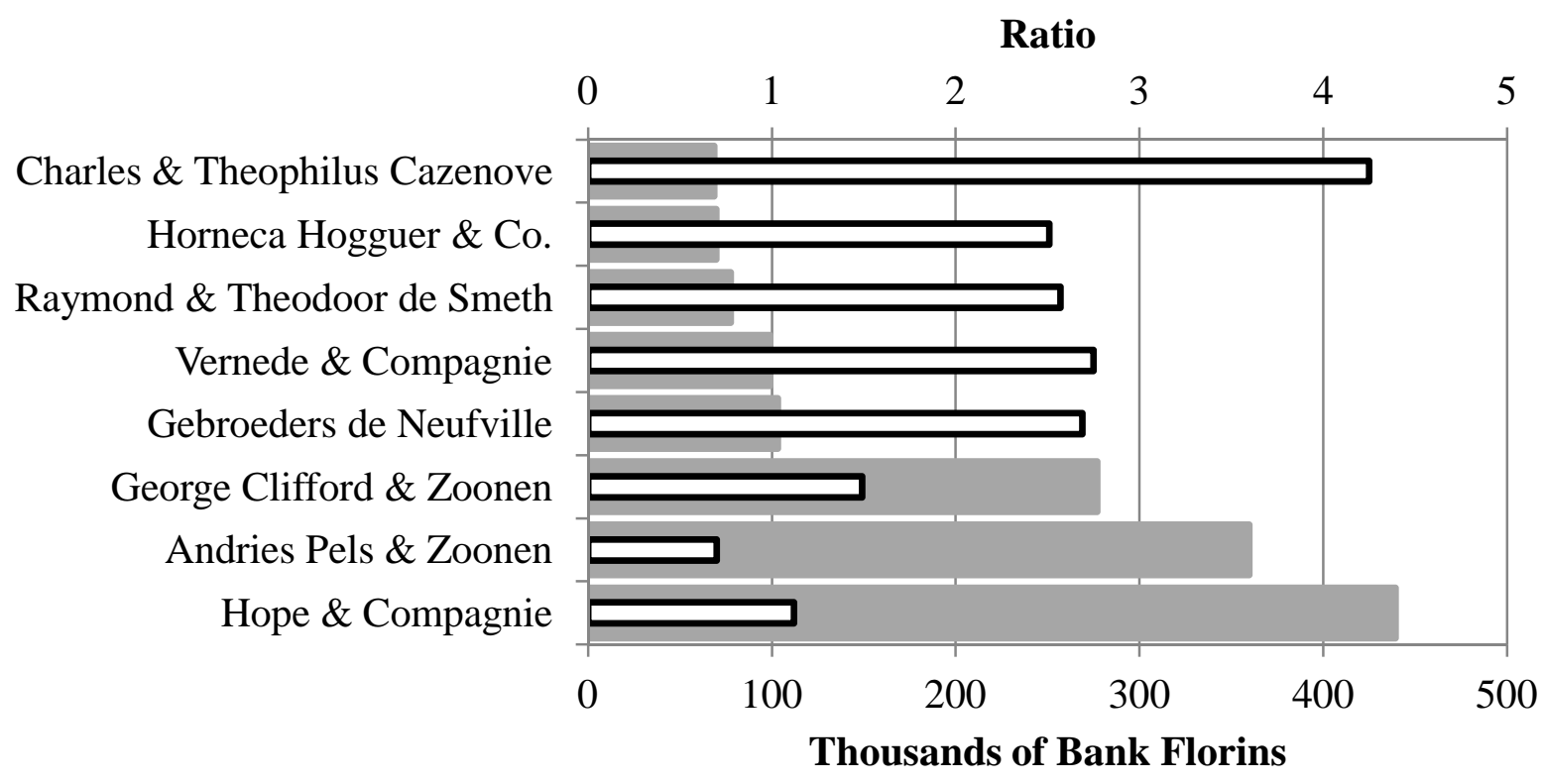

Average Weekly Balances (bottom axis)

口Average Weekly Expenditures over Average Weekly Balances (top axis)

Source: Stadsarchief Amsterdam 5077.

The data in Figure 2 can also be combined with data from de Neufville's bankruptcy filing (de Jong-Keesing 1939, 121) to shed some light on de Neufville's investment strategy. The house of de Neufville suspended payments on July 30 with liabilities of 9.6 million florins, mostly in bills, and (book) capital of 413 thousand florins, implying a leverage of 24 times capital. De Neufville's weekly settlements through the Bank amounted to about 239,000 florins, implying that least 2.5 percent of the firm's portfolio was rolled over through the Bank during an average week. $^{19}$

\footnotetext{
${ }^{19}$ Neufville would have also had some bills payable in current money (de Jong-Keesing 1939, 93).
} 


\section{Collateral Shocks}

The Seven Years' War led to a sharp expansion in lending activity in Amsterdam. The Amsterdam bill market financed a wide range of activities associated with the war, including the movement of military supplies, the floatation of sovereign loans, and movements of specie designed to take advantage of fluctuating exchange rates (de Jong-Keesing 1939, 55-86, Henderson 1962, 94-95). The countdown to the August 1763 panic began with the slowdown of hostilities in late 1762. The Treaty of Hubertusburg (February, 1763) concluded the war and spawned two shocks that diminished the value of the collateral (implicitly) backing Amsterdam’s bill transactions.

The first shock was a drop in the value of grain: prices in Berlin and Hamburg dropped by 30 percent between November 1762 and May 1763. Then, in May 1763, Prussia decided to dump its unused wartime grain supplies on the Berlin market, leading to a 75\% drop in the local price of wheat, with other agricultural prices soon following (Schnabel and Shin 2004, 956-959). These sudden price movements weakened many Amsterdam counterparties abroad and some of the Amsterdam traders themselves.

The commodity price shock was compounded by a monetary policy reversal. During the war, Prussia conducted a series of debasements that moved its monetary standard (i.e., mint equivalent) from 14 Reichsthalers per mark of fine silver to 40 thalers per mark for some coins (Koser 1900, 341-351). The wartime inflation was extremely unpopular with the nobility, so in May 1763 Prussia demonetized the depreciated war coinage and reduced the mint equivalent of new Reichsthalers to a "transitional” level of 19.75 thalers per mark (Henderson 1962, 96). Prussian merchants holding debased wartime coinage saw the nominal value of their collateral cut in half, and they responded by funding immediate debts with new bills drawn on markets such as Hamburg and Amsterdam. They also sent the demonetized coins to the same cities in the hopes of finding higher value as bullion (Büsch 1797, 123; Skalweit 1937, 45).

The Amsterdam market seems to have become quickly flooded with this type of debt and collateral. de Jong-Keesing (1939, 88, note 4) cites a May 31 letter by the Amsterdam merchant De Vogel to his Hamburg correspondent Emanuel Jenisch, describing the state of the Amsterdam money market at that time: 
It is to our regret that the circumstances of business are now such that we cannot make our correspondence profitable ... money is extremely scarce and the discount of first-rate bills is running at 5 percent ${ }^{20}$ in Bank money ... . The crude bars of silver that are being smelted here from the money arriving in great quantities from Germany, cannot be sold and are everywhere being borrowed against; these are also being discounted by 7 percent. ... Everything is bad for business.

Both shocks directly affected de Neufville. Before the drop in grain prices, de Neufville had collaborated with a "friend,” prominent Berlin merchant Johann Ernst Gotzkowsky, in a disastrous deal to purchase a million florins' worth of grain from the departing Russian army at the war's end (Skalweit 1937, 94-95). The firm had also anticipated receiving a contract from the Prussian crown to deliver silver for the new coinage, but this deal did not materialize (Spooner 2002, 82).

But the proximate cause of the failure of Gebroeders de Neufville was the suspension of payments by the minor firm of Aron Joseph en Compagnie on July 28, 1763 (de Jong-Keesing 1939, 121). De Neufville’s exposure to Aron Joseph was 163,000 florins, small relative to de Neufville's total book of 10 million florins, but meaningful in the context of its 239,000 florin weekly funding requirement. De Neufville suspended its payments at the Bank on July $30 .^{21}$

The failures had only an indirect effect on the Bank of Amsterdam, as the Bank itself was unlikely to be subject to runs. ${ }^{22}$ Coin receipts issued by the Bank were viewed as extremely secure, and their holders saw little reason to sell their redemption options at a time of financial unrest. Account holders without receipts could no more run the Bank than a modern holder of fiat money can run a modern central bank. But outside the Bank, de Neufville’s failure caused a sudden, extraordinary demand for coins. The market suddenly bid down the agio (premium) of Bank money, denominated in bank florins, against coin, denominated in current guilders. The next section will show that Bank funds were still in high demand to settle accepted bills of exchange that were now coming due, yet the agio fell to a discount of $1 / 2$ percent on Saturday, August 6. After two days and a central bank intervention (see Section 7 below), the agio bounced back up to positive territory, but the emergence of a negative agio was stunning development. It had been observed only once before, during the French invasion of 1672 (Quinn and Roberds 2010, 16). The

\footnotetext{
${ }^{20}$ Two to three percent was normal (Schnabel and Shin 2004, 942).

${ }^{21}$ It is reasonable to suppose that by this point, de Neufville had exhausted all other sources of funds; unfortunately our data do not allow us to directly verify this hypothesis.

${ }^{22}$ However, it is likely that the Bank did feel pressured, as evidenced by its not making any new loans to the East India Company after August 1763, and the Bank made no loans to the company in 1764.
} 
effect on market sentiment was not unlike the effect of negative T-bill rates the wake of the Lehman failure (Derby and Rappaport 2008).

Another indication of the severity of the liquidity crisis outside the Bank of Amsterdam came from Amsterdam’s most important satellite market, Hamburg. In Hamburg, claims against de Neufville amounted to around three million florins, spread over 38 counterparties (de JongKeesing 1939, 102). The bill market there was faced with virtual collapse. On August 4, a group of prominent Hamburg merchants sent a petition to Amsterdam, demanding a bankruptcy preference, and threatening a shutdown of their market for Amsterdam bills if this was not granted: ${ }^{23}$

This morning ... we received a fatal express, with the terrible news that you, the gentlemen of Amsterdam, would leave the Neufvilles to sink, by which we were all thunderstruck; never dreaming that so many men in their senses in your city could take such a step ... which will infallibly plunge all Europe in an abyss of distress, if not remedied by you whilst it is still time.

A proposal for a bailout was rejected after some debate, ${ }^{24}$ and the Hamburg merchants' threat only served to initiate a three-month long shutdown of the Amsterdam market for Hamburg bills. Surviving records indicate either no bill trade or sparse quotations for Amsterdam bills drawn on virtually all locations, over July-October $1763 .{ }^{25}$ When bills could be sold they went at depressed prices, even if they were drawn on places unaffected by the de Neufville failure (de JongKeesing 1939, 167). ${ }^{26}$ For example, annualized borrowing rates using London jumped from 4 percent to over 10 percent ${ }^{27}$ despite the efforts of London bankers to assist their Amsterdam correspondents (Wilson 1941, 168-9).

To preserve their own liquidity, Amsterdam bankers protested virtually all incoming bills drawn by Hamburg counterparties (de Jong-Keesing 1939, 166-171). In Hamburg, this blockade of acceptance credit forced 93 firms into bankruptcy during the month of August (Soetbeer 1855, 52; Schnabel and Shin 2004, 943-944). Similar shutoffs of credit and clusters of failures occurred in

\footnotetext{
${ }^{23}$ See Soetbeer $(1855,51)$ and Sautijn Kluit $(1865,25-26)$; English translation is from Tooke $(1838,149-150)$.

${ }^{24}$ The size of the proposed private bailout fund ("super SIV") was some 700,000 guilders. It was rejected largely due to the unpopularity of the Neufvilles (de Jong-Keesing 1939, 121; Spooner 2002, 83.)

${ }^{25}$ Including bills drawn on Breslau, Danzig, Hamburg, Lisbon, Livorno, London, Paris, and Vienna. See de JongKeesing (1939, 168-171) and Schneider et al. (1991, 66-101).

${ }^{26} \mathrm{~A}$ similar situation occurred in late 2007 when many ABCP conduits were indiscriminately run (Covitz et al. 2009).

${ }^{27}$ See Appendix I for calculations.
} 
other places dependent on the Amsterdam bill market, including Berlin (Skalweit 1937, 50) and Stockholm (de Jong-Keesing, 193-198). ${ }^{28}$

\section{Loss of liquidity in the Amsterdam bill market}

The direct exposure of Amsterdam bankers to de Neufville was rather limited. Rumors had been circulating for some time concerning de Neufville's solvency, and most of the large firms appear to have limited their exposure accordingly. ${ }^{29}$ Instead, the contraction of the bill market constricted the ability of the Amsterdam merchant bankers to roll over funding (draw bills on debtors). Although the bankers did not issue deposits and could therefore not be "run" in the classical sense, they faced a broadly equivalent loss of "funding liquidity" (Brunnermeier 2009, 91). The bankers were subject to an immovable requirement to settle accepted bills: since the maturity ("usance”) of bills drawn on Amsterdam was six weeks to two months (Schneider et al. 1991, 66-101), each bank would have begun the panic with an outstanding stock of settlement obligations.

Loss of liquidity is evident in the payments data. One measure of market density is given by a metric similar to that used by McAndrews and Rajan (2000) to study intraday payment flows over Fedwire. This is the percentage of interaccount payments funded through incoming transfers

$$
P I T_{t} \equiv 100\left(1-N R_{t}\right)
$$

\footnotetext{
${ }^{28}$ From the viewpoint of the Amsterdam banks, the blanket protests of foreign bills were justifiable as a way to insulate themselves from potential insolvencies of Neufville's counterparties. To the merchants in the outlying markets, these protests seemed like nothing more than a liquidity grab; a common complaint was that Amsterdam bankers even protested bills that were covered by goods received and therefore posed no credit risk to the drawee (Skalweit 1937, 86). Our data do not allow us to distinguish between these views.

${ }^{29}$ The exception was de Smeth, whose bankruptcy claim against Neufville amounted to 318,750 bank florins (de Jong-Keesing 1939, 110), twice its average weekly funding need (Figure 2).
} 
where $N R_{t}$ is the ratio of net to gross "interaccount" ${ }^{30}$ payments observed during week $t$, calculated as

$$
N R_{t} \equiv 0.5\left(\sum_{i=1}^{9} \mid \sum_{j=1}^{9} X_{i j t}-\sum_{j=1}^{9} X_{j i t}\right) /\left(\sum_{i=1}^{9} \sum_{j=1}^{9} X_{i j t}\right)
$$

The closer the value of $P I T_{t}$ to 100 , the more symmetric the flows of liquidity, and the less need for banks to fund their settlement positions by providing additional collateral. Figure 3 charts the evolution of $\mathrm{PIT}_{t}$ over the data sample.

Figure 3: Percentage payments funded by incoming transfers, 1763:1-1764:1

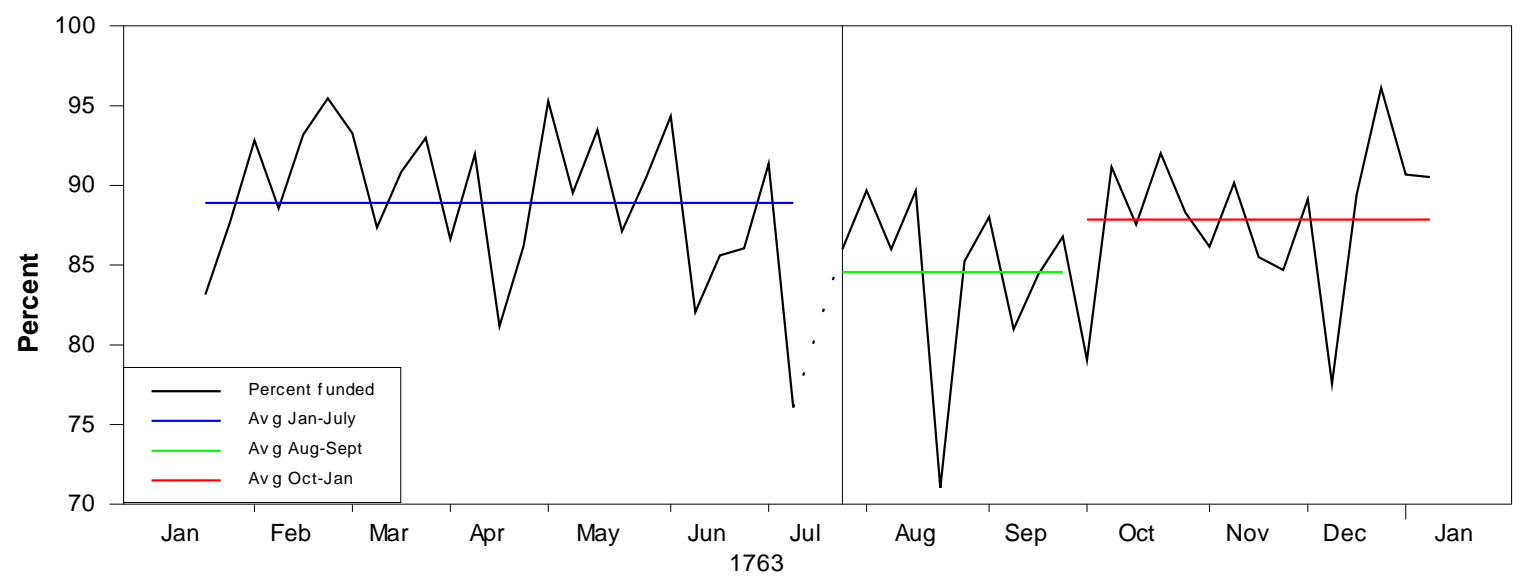

Source: Stadsarchief Amsterdam 5077.

The mean weekly percentage of payments funded through incoming transfers is about 89 percent before the de Neufville failure, but drops to 85 percent over the two months following the outbreak of the crisis, indicating a greater need to fund positions through the posting of collateral. ${ }^{31}$ In the last four months of the sample, there is a recovery to 88 percent.

\footnotetext{
30 “Interaccount” transactions are defined as transactions between two private accounts, i.e., ledger entries that do not involve the movement of metal into or out of the Bank.

${ }^{31}$ It is interesting to contrast these figures with those of other payment systems. Figures for the New York Clearing House over the period 1854-1908 imply a daily PIT of about 95 percent (Cannon 1910, 221). For modern largevalue systems, daily figures of over 99 percent are common (Bech and Hobijn 2007). The relatively high liquidity demand in our sample probably arises from (1) the comparatively sparse flow of payments, (2) incompleteness of the data sample, and (3) the absence of tiering (settlement through third parties), as compared to later systems dominated by deposit banks.
} 
Another method of measuring changes in liquidity pre- and post-crisis is to calculate the total value of payments made through the ten accounts we track, i.e., $T V_{t} \equiv \sum_{i=1}^{10} \sum_{j=1}^{10} X_{i j t}$. Mean weekly payments value declines from 4.17 million florins (pre-Neufville failure) to 2.97 million florins (post-Neufville), a drop of over 25 percent. ${ }^{32}$ Figure 4 gives some indication of the precipitous decline in non-bank payments. ${ }^{33}$ The figure decomposes the total value of payments according to source of origination. The groups are (1) interaccount transactions originating from the three large established banks; (2) interaccount transactions originating with the parvenus; (3) interaccount transactions originating from other Bank account holders (ROB); and (4) inflows of metal, in the form of either coin or bullion.

Figure 4: Payments value by source, 1763:1-1764:1

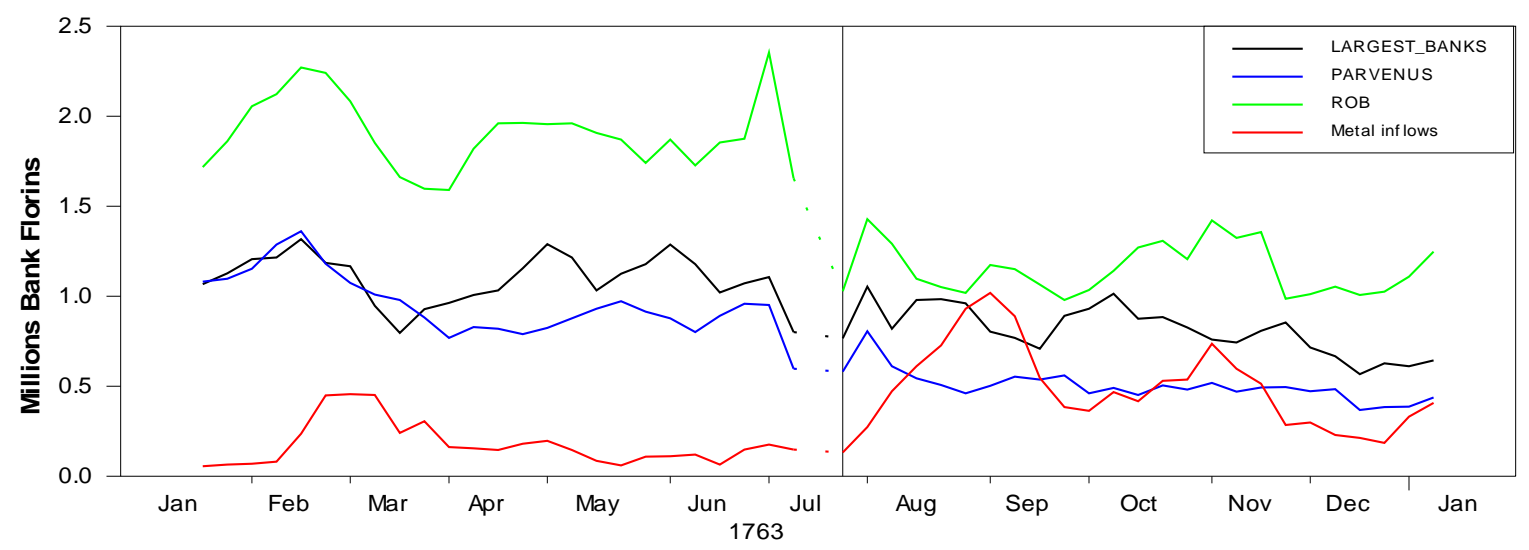

3-week moving averages. Source: Stadsarchief Amsterdam 5077.

The figure shows the abrupt dropoff in payments activity in wake of the de Neufville failure. The contraction is strongest in the rest of the Bank (ROB) proxy account, from a pre-crisis (JanuaryJuly 1763) level of about 2 million florins/ week to a lower level of about 1.1 million, reflecting a lower demand for bankers' bills. Payments originating with the bankers, by contrast, fall by a smaller amount, about 640,000 florins per week on average. ${ }^{34}$ Lack of market funding thus left

\footnotetext{
${ }^{32}$ Interaccount transfers drop even more sharply, by 37 percent.

${ }^{33}$ Corresponding weekly average figures are reported in Appendix A.

${ }^{34}$ This last figure can be further broken down into a reduction of 240,000 florins due to the demise of Neufville, and a 400,000 florin reduction in payments originated by the other banks. This implies that the seven surviving banks were able to reduce their bill obligations by about 23 percent. The reduced outflow of funds enabled the established banks to accumulate large precautionary balances; see Appendix B for a formal analysis of the flows of funds across banks.
} 
the bankers with a shortfall of about 270,000 florins per week, which was partly made up through metal deposits. Metal inflows into the bankers' accounts peak about six weeks into the crisis, a time frame roughly corresponding to the usance of bills drawn on Amsterdam in places such as Hamburg or Berlin.

The size of an individual bank's shadow run strongly correlates with each bank's leverage. For example, each bank's accumulation of net transfers in August and September, weighted by that bank's balance on July 29, has a strong correlation (-.89) with the bank's pre-crisis ratio of weekly payments-to-balances (see Figure 2). At one extreme, Pels, the most conservative bank, has a 10 percent decline in balances from net transfers. ${ }^{35}$ At the other, the aggressive Cazenove sees a 570 percent decline. The other declines fall in between with Hope at 49 percent, Horneca at 81 percent, Clifford at 167 percent, de Smeth at 168 percent, and Vernede at 266 percent.

To gain some perspective on these numbers, it is instructive to consider changes experienced in payments aggregates in the wake of the Lehman bankruptcy. The daily mean value of U.S. dollar payments over large-value systems ${ }^{36}$ falls from $\$ 8.6$ trillion in 2008 to $\$ 7.0$ trillion in 2009, a comparatively shallow reduction of 18 percent (Committee on Payment and Settlement Systems 2011, table PS-3). Higher frequency (monthly) statistics are available only for the Fedwire system $^{37}$, and these show a different pattern from that displayed in Figure 4. Fedwire payments activity peaks around the time of the Lehman failure (reaching an all-time high of \$3.2 trillion/day in September 2008) and declines only gradually thereafter. Thus, Figure 4 attests to a substantial and immediate contraction of the Amsterdam bill market in August 1763.

\section{Policy response}

The post-Neufville credit freeze-up ultimately forced 38 Amsterdam firms into bankruptcy during August and September 1763 (de Jong-Keesing 1939, 130-145). Compared to de Neufville,

\footnotetext{
${ }^{35}$ See Appendix B.

${ }^{36}$ This is a measure of the daily value of funds flows needed to settle financial transactions denominated in U.S. dollars. Computed as sum of the annual value of payments over Fedwire, the value of payments over CHIPS, and 85 percent of the value of payments over the multicurrency CLS system, all divided by 250. See Bech, Martin, and McAndrews (forthcoming) for an overview of U.S. large value payment and settlement systems.

${ }^{37}$ www.frbservices.org/operations/fedwire/fedwire_funds_services_statistics.html.
} 
however, these were small enterprises, ${ }^{38}$ and many were able to reopen within a few months, after settling with creditors. ${ }^{39}$ By October, there are signs of the market returning to a more "normal" state, albeit at lower levels of activity than before (Figure 4). These include a return of the agio to a more normal range (Appendix J), an increase in the percentage of payments funded through incoming transfers (Figure 3) and a recovery of the exchange rate (Appendix I). The Amsterdam market as a whole was able to escape the devastation that took place in outlying locations.

This section will argue that a major reason for the comparatively mild impact of the panic in Amsterdam was the provision of liquidity through the Bank of Amsterdam, which was able to compensate for a shortage of market liquidity. As hinted at in Figure 1, demand for Bank balances was accommodated through two mechanisms. The first was the traditional "repo" (i.e., receipt) window for trade coins. The second was a new facility, a receipt window for unminted silver bullion. The bullion window was authorized on August 4, and the first transaction using this window was recorded on August 6, the day the agio turned negative. ${ }^{40}$

\subsection{Coin window}

While coin deposits at the Bank of Amsterdam functioned much as modern central bank repurchase transactions, the Bank did not try to actively vary the terms of its coin window. Nor did it attempt to manage the quantity of receipts outstanding, but simply allowed these to adjust to market conditions. ${ }^{41}$ Thus, much of post-Neufville adjustment in the money stock can be attributed to endogenous shifts in the use of this facility, reflecting changes in market strategies of the merchant banks.

The rapid drop in expenditures by non-banks after the failure of de Neufville (see Figure 4) meant that that net transfers flowed relentlessly from bankers for two months. To maintain their

\footnotetext{
38 The next largest bankrupt after Neufville was Cornelis Karsseboom, with liabilities of 3.5 million guilders (de Jong-Keesing 1939, 146). The average liability of a bankrupt was 669,000 guilders (Schnabel and Shin 2004, 963).

${ }^{39}$ Settlements were common, given that statutory resolution of bankruptcy could last up to 33 years.

${ }^{40}$ For authorization, see van Dillen (1925, 412). For start, see Amsterdam Stadsarchief 5077/1390, p. 30.

${ }^{41}$ In modern terminology the Bank operated a "standing facility," rather than conducting open market operations using repos. The line between these two types of policies is not always precise. E.g., the European Central Bank engaged in a number of fixed-rate open market operations of indefinite size ("fixed rate tenders with full allotment”) in order to meet post-Lehman demands for liquidity; see Catalão-Lopes (2010).
} 
overall balances, the seven surviving bankers created 2 million new florins by bringing coin collateral into the bank. This channel generated large amounts of liquidity without the Bank taking any new policy action.

To see this at the firm level, Figure 5 displays the weekly balances of a particular merchant bank, Horneca Hogguer en Compagnie, from the day before the de Neufville failure, to the end of the Bank's fiscal year. While Horneca Hogguer's baseline balances stay positive, removing the liquidity created by Horneca Hogguer through the coin window reveals that net transfers out of the bank were substantial. Without new coin receipts (repos), the account would have gone illiquid the week of August 8. Horneca Hogguer did not make use of the bullion window.

Figure 5. Weekly balances of Horneca Hogguer

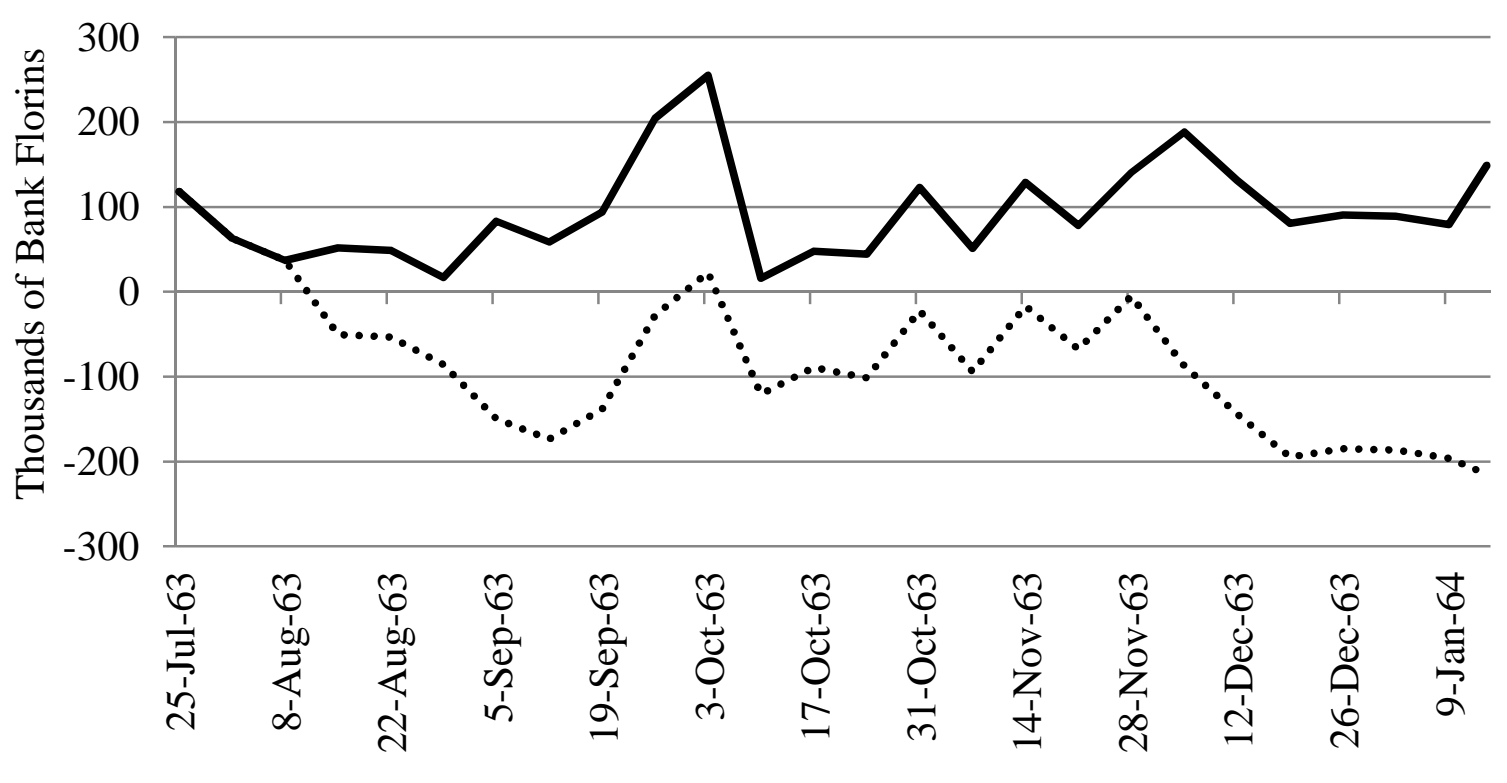

Without Coin Window $\quad$ Baseline

Source: Stadsarchief Amsterdam 5077.

At the other extreme, Hope, the largest merchant bank, was not threatened with imminent failure, but it too suffered a shadow run, and it too used the coin window to maintain balances. To see the run and response, Figure 6 gives Hope's weekly balance and those balances stripped of coin window activity. Through August-September, Hope lost 600,000 bank florins in net transfers, but coin inflows kept the bank's balances above 500,000. 
Figure 6. Weekly balances of Hope

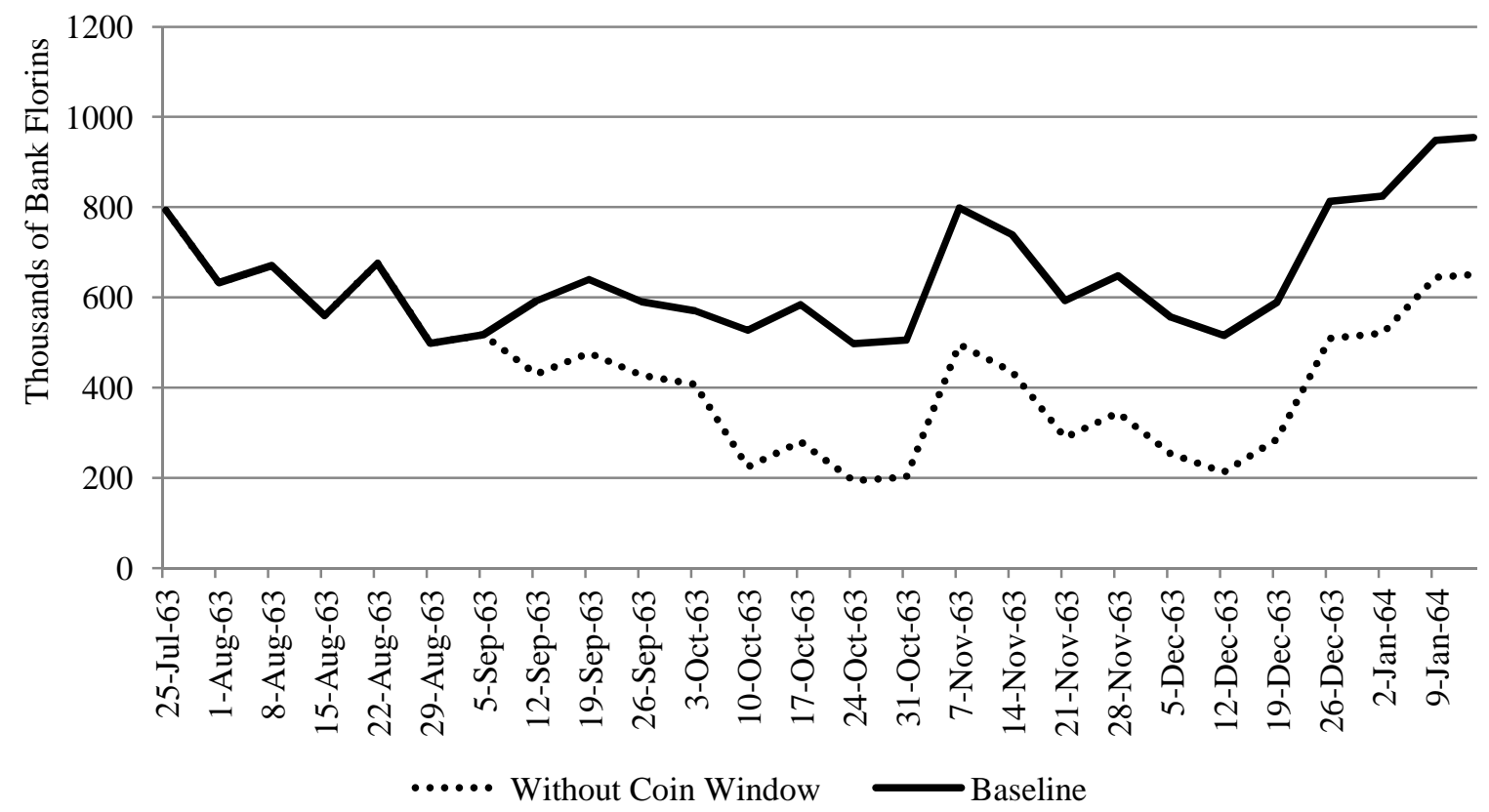

Source: Stadsarchief Amsterdam 5077.

\subsection{Bullion window-design}

The policy dilemma facing the facing the Bank of Amsterdam in August 1763 is easily recognized from the recent crisis: an extraordinary demand for central bank balances, combined with a surfeit of collateral, only most of it (silver bullion in particular) not eligible for transactions with the central bank. Somewhat differently from 2008, it was possible for market participants to convert ineligible collateral (bullion) to eligible collateral (trade coins) by taking the former to a mint. Many people did take bullion to the mints, but production was slowed by technological and labor issues (de Jong-Keesing 1939, 50), and, we suspect, a surge in demand that exceeded capacity constraints. ${ }^{42}$ Our reconstruction of Polak (1998) shows an extraordinary jump in Dutch mint production in 1763 and $1764 .{ }^{43}$ Moreover, production focused on current guilder coins:

\footnotetext{
${ }^{42}$ Mints functioned essentially as private operations subject to government regulation (de Jong-Keesing 1939, 51).

${ }^{43}$ See Appendix F.
} 
non-trade coins that were useful in the domestic Dutch economy but had no receipt window at the Bank. The quantity and type of Dutch minting further indicate of how tight liquidity was outside the Bank of Amsterdam.

The improvised solution was for the Bank to expand its repo window to include uncoined bullion. In designing this program, a key political constraint was that the Bank not undercut the business of the mints, a major source of governmental revenue. Accordingly, the new window had to deliver fewer florins than the turning of bullion into a new coin. The Bank satisfied this constraint by fixing the bullion "bank price” at 22.91 florins per mark pure silver. ${ }^{44}$ In 1763 , most large silver coins produced by the Dutch Republic had a mint price of 25.1 current guilders per mark (Polak 1998), so minting bullion and then selling the resulting coin at the market agio (denoted as $a$, a percent premium) would produce the same florins as the bullion window as long as

$$
25.1 \times\left(\frac{1}{1+a}\right)=22.91 \text {, or } a=.0956 \text {. }
$$

Hence, the bullion window would not improve on the minting and the subsequent selling of new coins unless the agio was above $9 \frac{1}{2} 2$ percent. In 1763, the agio was in the 2 to 3 percent range. Alternatively, people could bring new coins to the Bank. For that purpose, the most attractive coin was the ryxdaalder, for it had a combined mint-and-receipt value of $24.1^{45}$ florins per mark, and that value was distinctly more attractive than the 22.91 offered by the window.

Yet the new window still appealed to people who needed florins immediately or did not want to risk tying up their collateral at the mint. There already existed two ways to rapidly convert bullion into florins: use the bullion as collateral for a private loan or sell the bullion on the open market. The new window improved on the collateral approach. The bank charged a 1.0025 percent annualized rate (6 months at a $1 / 2$ percent). Three months before the panic, lenders were charging as much as 7 percent (we assume annually) for loans against bullion. ${ }^{46}$ The short-term

\footnotetext{
${ }^{44}$ For bullion of 11/12ths fineness or better, the bank price was 21 bank guilders per mark (van Dillen 1925, 412). Less fine bullion was credited at fewer bank guilders per pure mark.

${ }^{45} 24.1=$ (25.1 current guilders per mark fine silver)*(2.4 bank guilders per coin/2.5 current guilders per coin).

${ }^{46}$ See the discussion on p. 18 above.
} 
rates during the crisis were higher still, if a lender could be found at all. Hence, the Bank's window offered guaranteed access to loans at an attractive rate. ${ }^{47}$

The penalty for use of the window was given by an implicit "haircut," for the market price of bullion was well above the 22.91 offered by the Bank. To calculated the value of the haircut, we first note that the market value of bullion in florins was the price of a mark of pure silver in current guilders $\theta$, converted using the agio $a$. The value of silver at the new window equals the market if

$$
\theta\left(\frac{1}{1+a}\right)=22.91
$$

However, no source records a value of $\theta$ below 25 current florins (de Jong-Keesing 1939, 92; Nogues-Marco 2011, 44), for the mint price of 25.1 created a price floor. Thus, equation (5) implies that at a market agio of 2 percent, and an implied market silver price of 24.5 florins per mark, the bullion window's haircut was around 6 percent. ${ }^{48}$ This meant that 1 ) the window was less accommodating than first appears, 2) borrowers had a strong incentive to execute the repurchase (endogenously unwind) when conditions calmed and 3) the window did not disrupt the normal sale of bullion. It did, however, provide a backstop to the bullion market. ${ }^{49}$

\subsection{Bullion window-usage}

While much smaller in scale than coin receipts (see Figure 1), we find that the bullion window made a critical difference for some players. Figures 7 and 8 report the evolution of balances for the firms Cazenove and de Smeth, respectively. Each figure separately strips balances of coin window liquidity (dots) and bullion window liquidity (grey). ${ }^{50}$ Without the addition of bullion

\footnotetext{
${ }^{47}$ This may have been possible only because by tradition, the Bank enjoyed much the same creditor protection as a modern repo lender. By contrast, private creditors who lent to Neufville against bullion collateral were fully compensated, but only after several months’ lag (de Jong-Keesing 1939, 124).

${ }^{48}$ Private creditors may have haircut such collateral even more aggressively, however; loans to Neufville made against metal collateral carried a haircut of 25 percent (de Jong-Keesing 1939, 93).

${ }^{49}$ We note that many of the facilities created in response to the 2008 crisis also incorporated Bagehotian pricing. E.g., ABCP purchased by the Fed's Commercial Paper Funding Facility (Adrian et al. 2010) was priced at a 300 basis point penalty over the overnight index swap rate, an unattractive rate under normal market conditions.

${ }^{50}$ Bullion includes funds dispersed through an ad hoc account created from barrel (vaaten) silver; see Appendix E.
} 
receipts, Cazenove would have become illiquid the week of August 22. De Smeth needed bullion towards the end of September when a second wave of payments would have eaten his balances. ${ }^{51}$

Thus, under the defensible assumptions that Cazenove's and de Smeth's transactions are predetermined over the months of August and September (due to usance conventions), and that their use of the bullion window demonstrated that they had little or no coin left to serve as collateral (due to the Bank's haircut), it is reasonable to conclude that use of the bullion window prevented the failure of two more "parvenu" banks — market players of approximately the same size and leverage as de Neufville (Figure 2).

Figure 7. Weekly balances of Cazenove

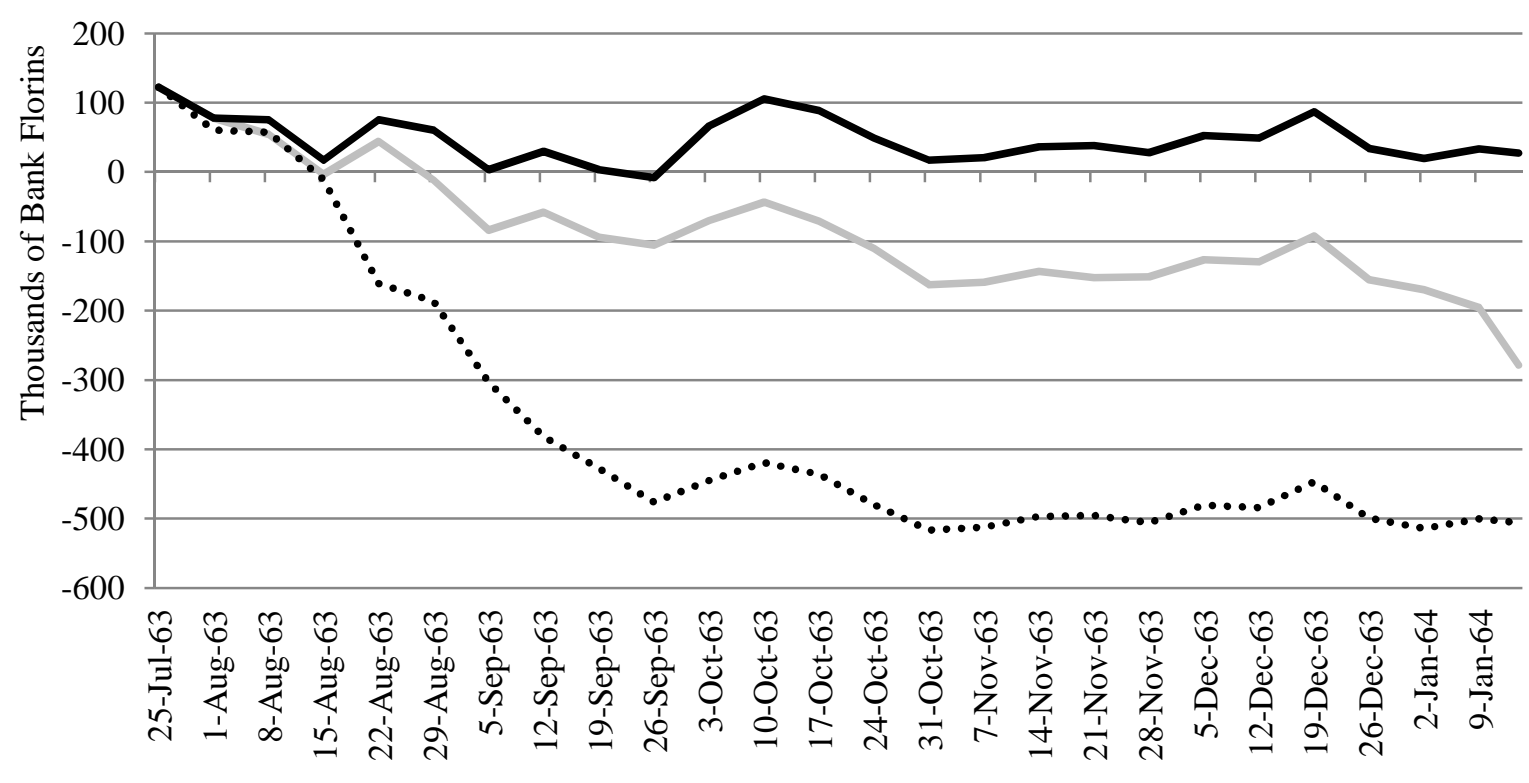

Without Bullion Window

Without Coin Window

Baseline

Source: Stadsarchief Amsterdam 5077.

\footnotetext{
${ }^{51}$ Without bullion, Vernede's balances would have been positive but reduced to only 5,458 bank florins the week of August 15.
} 


\section{Figure 8. Weekly balances of de Smeth}

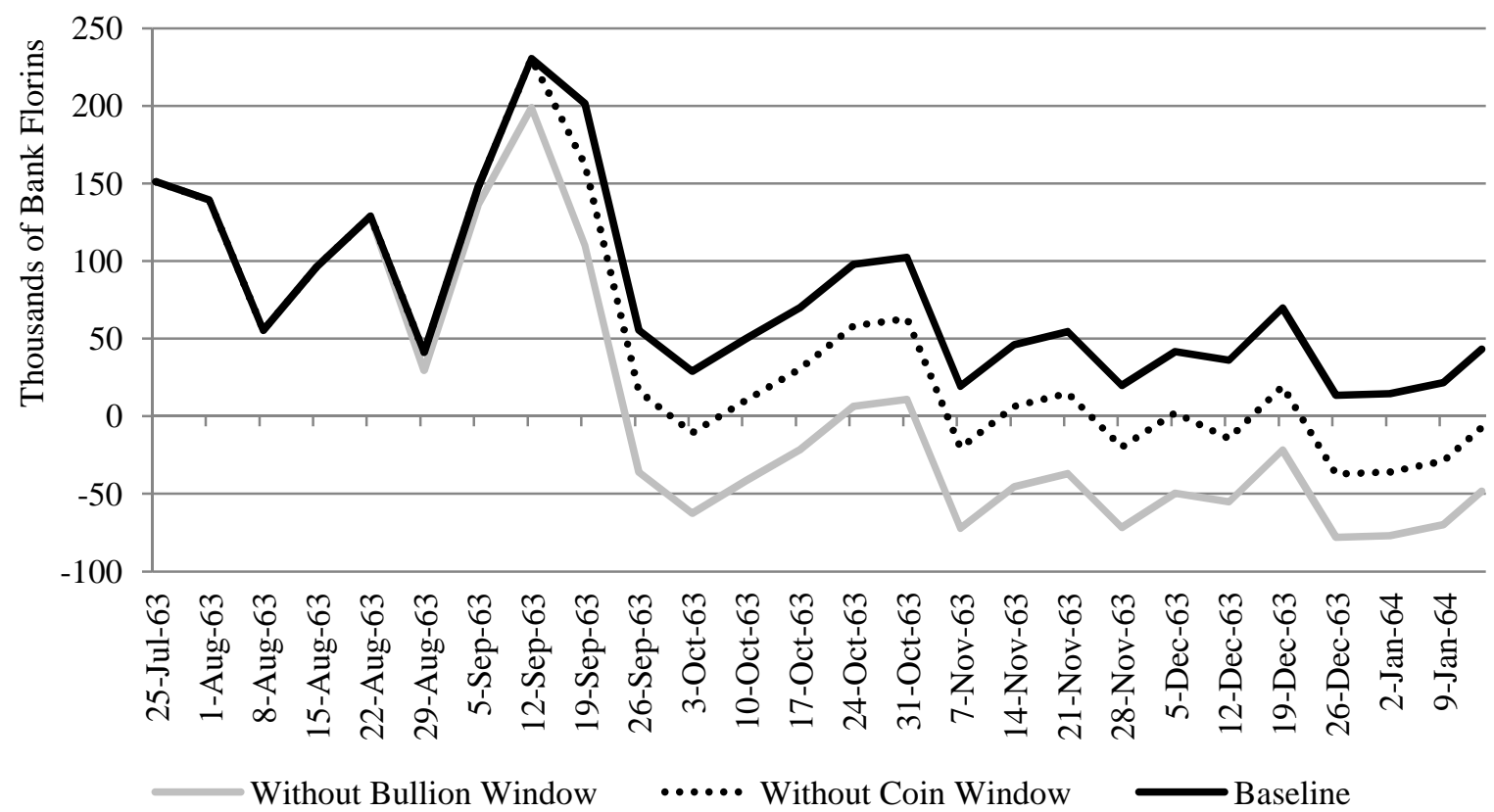

Source: Stadsarchief Amsterdam 5077.

\subsection{Knock-on effects}

If there had been no bullion window and if Cazenove and de Smeth had failed, would additional banks have failed? To investigate this question, we turned to the simulation methodology of papers in the "contagion" literature. ${ }^{52}$ To apply this methodology, we again interpret the postNeufville payments data $X_{i j t}$ as a set of obligations predetermined at the outset of the crisis. ${ }^{53} \mathrm{~A}$ hypothetical sequence of balances is then constructed by taking initial balances at the outbreak of the crisis, and removing inflows from the bullion window, as well as payments due to and due

\footnotetext{
${ }^{52}$ See e.g., Upper (2007) or Mistrulli (2011) for expositions of this methodology.

${ }^{53}$ As in the earlier exercises, this is partly justified by an appeal to usance conventions. I.e., after the Neufville failure, banks were able to whittle down new settlement obligations by protesting bills, so what was left was the stock of bills that had already been accepted —or that the bankers felt they had to accept in order to stay in business.
} 
from failing banks (Cazenove and de Smeth). ${ }^{54}$ This exercise indicates that two other banks would have experienced noticeable impacts, Horneca Hogguer and Hope.

Figure 9: Simulated balances with no bullion window +2 failures
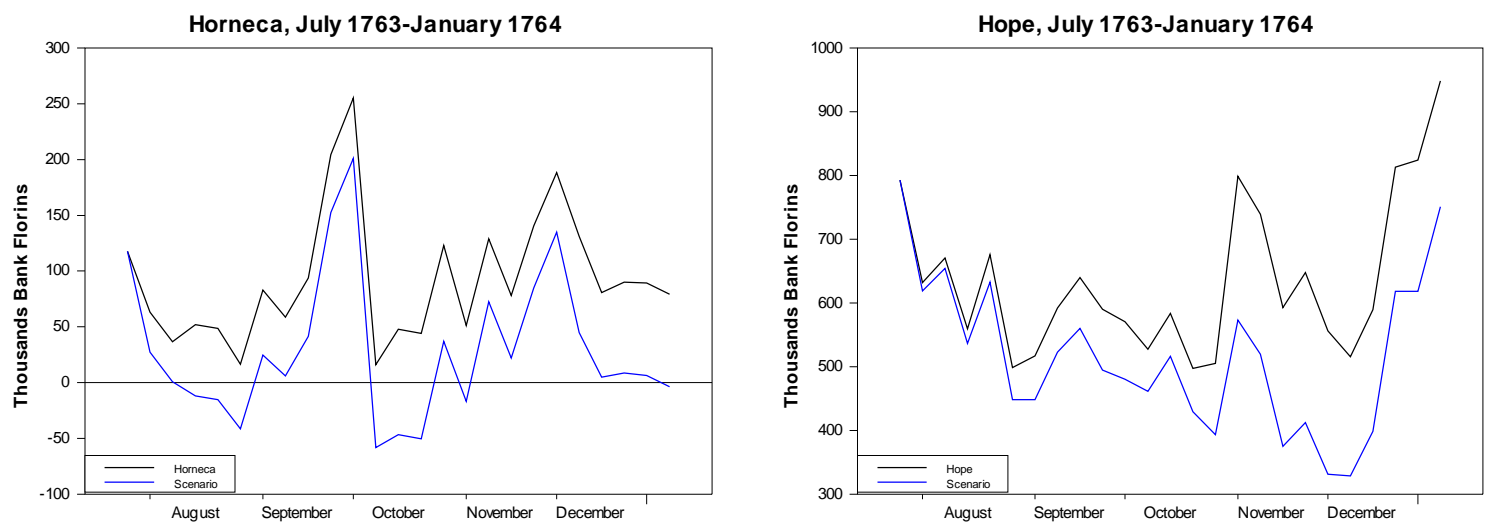

Source: Stadsarchief Amsterdam 5077.

Figure 9 contrasts the evolution of balances under the contagion scenario against their realized values in the data. The simulation has Horneca Hogguer (cf. Figure 5 above) becoming illiquid during the week of August 8. Assuming that bank accelerated its deposit of 130,000 florins worth of coins from late to early August, Horneca Hogguer would still have needed 50,000 additional florins to meet its payment obligations.

Of the remaining four banks, the biggest effects are for Hope, with a cumulative reduction in balances of about 200,000 florins. ${ }^{55}$ This loss comes primarily late in the year, however, so the number serves as more of an upper bound than a point estimate of the loss. Buist $(1974,520)$ puts the capital of Hope en Compagnie at 4.6 million current guilders in 1763, suggesting that Hope would have easily absorbed shortfalls stemming from the failures of additional parvenus, so long as asset liquidation was not a problem. ${ }^{56}$ Nonetheless, even for Hope, 200,000 florins

\footnotetext{
${ }^{54}$ This exercise assumes that Cazenove and de Smeth fail at the outset of the crisis. Variations on this assumption yield substantially similar results.

${ }_{55}$ This figure does not change by much if we assume that Horneca Hogguer also fails.

${ }^{56}$ This inference is buttressed by Hope's offer to contribute half a million guilders to the bailout fund that was proposed at the beginning of the crisis (van Dillen 1922, 249).
} 
would have been a nonneglible sum, equal to 44 percent of the firm's distributed profits for the year (Buist 1975, 521).

The above exercise does not calculate additional knock-on failures within the rest of the Bank of Amsterdam. This is a limitation of our data, but experience with de Neufville suggests that more bankruptcies likely would have resulted, both within Amsterdam and abroad. It is probable that the bullion window succeeded in stopping an additional batch of failures, even if we do not know the number and magnitude of these. For example, Figure 10 contrasts how bankers and the rest of the Bank created funds during August and September. Non-bankers relied on the bullion window for 48 percent of their liquidity creation compared to 14 percent for the seven bankers, so non-bank demand for bullion repos was greater both in total and in proportion to other collateral types.

Figure 10: Net Deposits in August-September 1763

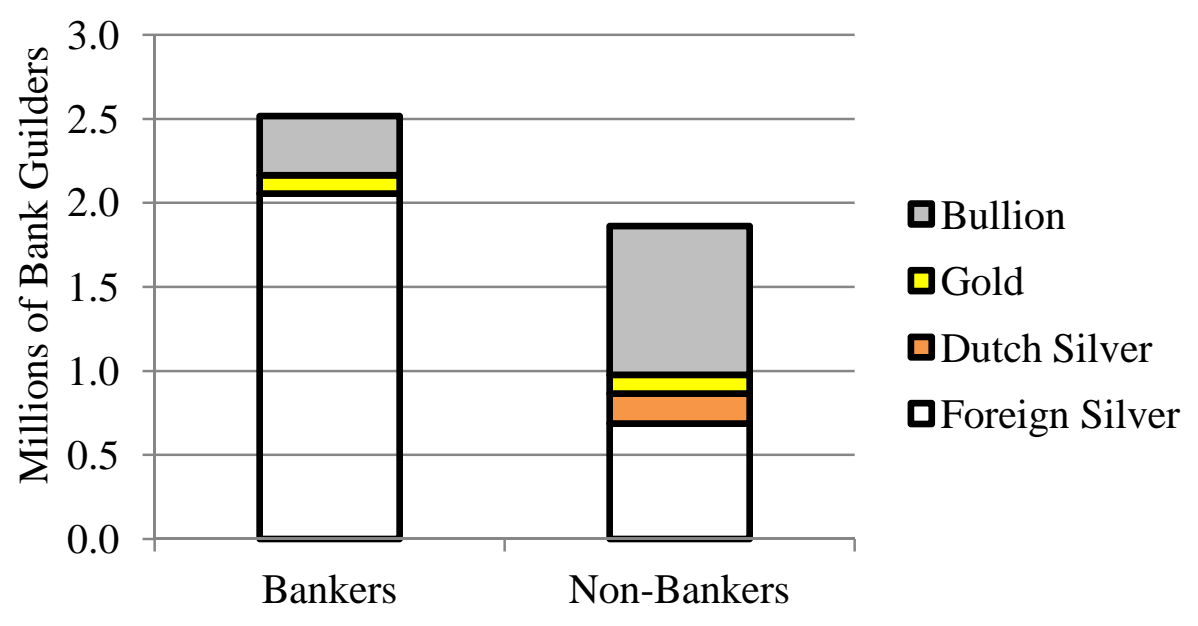

Source: Stadsarchief Amsterdam 5077.

Everyone stopped using the bullion window after worst effects of the banking crisis in Amsterdam had passed. Outside Amsterdam, however, the Panic of 1763 only served to mark the beginning of a deep and long recession, most notably in Prussia (Schnabel and Shin 2004, 945-946). One consequence of the lingering effects of the crisis seems to have been a "flight to quality": net coin flows into the Bank of Amsterdam surged by 4.1 million florins in the fourth quarter, and the Bank reached its two-century maximum balance of 30.9 million florins (van Dillen 1925, 
962-6). While 18 percent of the last-quarter surge were ryxdaalders (likely newly minted), almost all the rest were Spanish dollars. ${ }^{57}$ This tsunami of silver receded the next year. ${ }^{58}$

\subsection{Paths not taken}

A modern observer might ask why the Bank of Amsterdam did not respond to the crisis using the more familiar central banking tools of discount window lending and active open market operations.

In the case of the former, the answer is simply that it was beyond the Bank's charter to lend to individuals or accept debt obligations (bills) as collateral. In the case of the latter, the available policy options would have worsened either the crisis inside the Bank or the crisis outside the Bank. The open market sale of coins by the Bank could lift the agio, but it would have also decreased the supply of bank florins. ${ }^{59}$ In addition, vault records indicate that at the time of the crisis, the Bank held only a modest stock of "unencumbered reserves" (coins not held under receipt; see Table 3), so a sale policy was not a realistic option. In contrast, purchases of coins would have increased liquidity within the Bank, but it would have decreased outside liquidity and put downward pressure on the agio. Bullion purchases ${ }^{60}$ posed similar problems, for silver bullion was rushing to the Dutch mints. Reducing this flow would disrupt seigniorage revenue to provincial governments, disrupt the increase in the supply of current money, and disrupt the resultant recovery of the agio. By opening a bullion window, the Bank avoided these problems, while still offering a Bagehotian balance of unlimited potential quantity at a price only the neediest would chose.

\footnotetext{
${ }^{57}$ Calculated using Amsterdam Stadsarchief 5077/1390, folios 47-9.

${ }^{58}$ Balances had fallen to 26 million by the end of 1764 and to $16 \frac{1}{1 / 2}$ million by the end of 1765 (van Dillen 1925, 996).

${ }^{59}$ Mees $(1838,109)$ reports that the Bank also feared that coins used to purchase Bank florins would quickly be shipped abroad, depriving Amsterdam of needed collateral.

${ }^{60}$ In the seventeenth Century, the Bank bought and sold bullion through open market operations (Quinn and Roberds 2010), but by the eighteenth century, its purchases consisted primarily of single-guilder coins that had no collateral rights at the Bank.
} 


\section{Lessons learned}

The Panic of 1763 records a distressingly familiar recipe for financial conflagration. Flammable ingredients include a system of securitization with numerous cross exposures (acceptance loans), an aggregate shock to collateral values (the end of the Seven Years’ War), and erratic policy decisions (on the part of the Prussian monetary authorities). The spark is provided by the collapse of a single participant (de Neufville) who is "too interconnected to fail" (in the view of Hamburg petitioners), but who fails nonetheless. Missing from the mix are the too-big-to-fail distortions of modern financial environments, but these seem not to have been necessary in the lightly regulated world of eighteenth-century finance.

The Bank of Amsterdam's firefighting efforts also displayed a light touch—by the standards of 2008-but our evidence shows that they were effective within the confines of the Amsterdam market. Unlimited amounts of liquidity were made available, on fixed terms, through the Bank's traditional (coin) repo window, a type of policy that would be repeated 245 years later. A second window was opened for less conventional assets (bullion). This window was lightly used, yet it was well designed for its limited purpose. It assisted a central niche of market participants, and did not disrupt adjustment processes occurring outside the Bank.

The two liquidity facilities, working in combination, prevented additional failures of major market participants, and contained the domestic fallout from the crisis. Working in the background was an important component of Amsterdam's financial infrastructure-the finality of settlement through the Bank of Amsterdam. Once settled through the Bank, a bill transaction could not be unwound, limiting the potential for knock-on failures in the Amsterdam bill market.

Within the narrow theater of the Amsterdam market, the Bank's response to the crisis can thus be judged a success. But the Bank could not route liquidity to where it was needed most - to satellite markets such as Hamburg and Berlin, where the flow of trade depended on unimpeded access to the Amsterdam bill market. Nor could the Bank prevent the mass unwinding of bill transactions through protests, which may have preserved the liquidity of the Amsterdam bankers, but which also led to a collapse of some outlying credit markets. Seen from Amsterdam, this may have seemed a fair outcome, since the underlying shocks had originated on the periphery. To 
people in the periphery, however, the punishment must have seemed disproportionate to the crime.

The Bank's mixed record leads to the following inference for the post-Lehman policy interventions. That is, that two key elements underlying the effectiveness of these interventions may have been those that were lacking in 1763: robust settlement institutions and the free flow of liquidity across national borders. 


\section{References}

Adrian, Tobias, Karin Kimbrough, and Dina Marchioni. 2010. “The Federal Reserve’s Commercial Paper Funding Facility.” Federal Reserve Bank of New York, Staff Report no. 423.

Allen, William A. and Richhild Moessner. 2010. "Central bank liquidity cooperation and international liquidity in the financial crisis of 2008-9.” Bank for International Settlements, Working Paper no. 310.

Allen, William A. and Richhild Moessner. 2011. "The international propagation of the financial crisis of 2008 and a comparison with 1931.” Bank for International Settlements, Working Paper no. 348.

Bech, Morten L. and Bart Hobijn. 2007. "Technology Diffusion within Central Banking: the Case of Real-Time Gross Settlement.” International Journal of Central Banking (September), 147-181.

Bech, Morten L., James T.E. Chapman, and Rodney J. Garratt. 2010. "Which bank is the 'central’ bank?” Journal of Monetary Economics 57, 352-363.

Bech, Morten L., Antoine Martin, and James McAndrews. Forthcoming. "Settlement Liquidity and Monetary Policy Implementation-Lessons from the Financial Crisis.” Federal Reserve Bank of New York Economic Policy Review.

Brunnermeier, Markus K. 2009. "Deciphering the Liquidity and Credit Crunch 2007-2008.” Journal of Economic Perspectives 23(1), 77-100.

Buist, Marten G. 1974. At spes non fracta: Hope \& Co. 1770-1815. Martinus Nijhoff, the Hague.

Büsch, Johann Georg. 1797. Versuch einer Geschichte der Hamburgischen Handlung nebst 2 kleineren Schriften verwandten Inhalts. Benjamin Gottlob Hoffman, Hamburg.

Cannon, James G. 1910. Clearing Houses. Report by the National Monetary Commission to the U.S. Senate, 61st Congress, 2nd session, Doc. 491. Government Printing Office, Washington, D.C.

Catalão-Lopes, Margarida. 2010. "Fixed- and Variable-Rate Tenders in the Management of Liquidity by the Eurosystem: Implications of the Recent Credit Crisis.” International Journal of Central Banking 6(2): 199-230.

Committee on Payment and Settlement Systems. 1992. Delivery versus Payment in Securities Settlement Systems. Bank for International Settlements, Basel.

Committee on Payment and Settlement Systems. 2003. A glossary of terms used in payments and settlement systems. Bank for International Settlements, Basel. 
Committee on Payment and Settlement Systems. 2011. Statistics on payment and settlement systems in the CPSS countries - Figures for 2009. Bank for International Settlements, Basel.

Copeland, Adam, Antoine Martin, and Michael Walker. 2010. "The Tri-Party Repo Market before the 2010 Reforms.” Federal Reserve Bank of New York, Staff Report no. 477.

Covitz, Daniel M., Nellie Liang, and Gustavo A. Suarez. 2009. "The Evolution of a Financial Crisis: Panic in the Asset-Backed Commercial Paper Market.” Finance and Economics Discussion Series no. 2009-36, Federal Reserve Board.

Dang, Tri Vi, Gary Gorton, and Bengt Holmström. 2009. "Opacity and the Optimality of Debt for Liquidity Provision.”

Davis, Lance and Robert Gallman. 2001. Evolving Financial Markets and International Capital Flows. Cambridge: Cambridge University Press.

Dehing, Pit, and Marjolein 't Hart. 1997. "Linking the fortunes, currency and banking, 15501800.” In A Financial History of the Netherlands, ed. Marjolein 't Hart, Joost Jonker and Jan Luiten van Zanden, 37-63. Cambridge University Press, Cambridge.

De Jong-Keesing, Elisabeth Emmy. 1939. De Economische Crisis van 1763 te Amsterdam. N.V. Intern. Uitgevers en h. Mij, Amsterdam.

Derby, Michael S. and Liz Rappaport. 2008. "Safety Trumps Yield in Bill Sales—Investors Scoop Up 0\% Short-Term Notes.” Wall Street Journal, 10 December.

De Vries, Jan and Ad van der Woude. 1997. The First Modern Economy. Cambridge University Press, Cambridge.

Ferderer, J. Peter. 2003. "Institutional Innovation and the Creation of the Liquid Financial Markets: the Case of Bankers’ Acceptances, 1914-1934.” Journal of Economic History 63: 66694.

Flandreau, Marc and Stefano Ugolini. 2011. "Where it All Began: Lending of Last Resort and the Bank of England during the Overend, Gurney Panic of 1866.” Graduate Institute of International and Development Studies Working Paper No: 04/2011.

Fleming, Michael J., Warren B. Hrung, and Frank Keane. 2010. "Repo Market Effects of the Term Securities Lending Facility.” Federal Reserve Bank of New York Staff Report \#426.

Goldberg, Linda S., Craig Kennedy, and Jason Miu. 2010. “Central Bank Dollar Swap Lines and Overseas Dollar Funding Costs.” NBER Working Paper 15763.

Gorton, Gary and Andrew Metrick. 2010. "Regulating the Shadow Banking System.” Brookings Papers on Economic Activity (Fall): 261-303. 
Henderson, W. O., 1962. “The Berlin Commercial Crisis of 1763.” The Economic History Review, New Series 15(1), 89-102.

Hoffman, Philip, Gilles Postal-Vinay and Jean-Laurent Rosenthal. 2000. Prices Markets: The Political Economy of Credit in Paris. Chicago University Press, Chicago.

Joslin, David M. 1954. “London Private Bankers 1720-1785.” Economic History Review, second series, 7, 167-186.

Kapperczyk, Marcin and Phillip Schnabl. 2010. "When Safe Proved Risky: Commercial Paper during the Financial Crisis of 2007-2009.” Journal of Economic Perspectives 24(1), 29-50.

Koser, Reinhold. 1900. Die preussischen Finanzen im siebenjährigen Krieg. Forschungen zur brandenburgischen und preussischen Geschichte, Leipzig.

Malinowski, Mikolaj. 2011. "Weekly Prices in Amsterdam in the $18^{\text {th }}$ Century.” International Institute of Social History, Historical Prices and Wages at www.iisg.nl/hpw/

McAndrews, James and Samira Rajan. 2000. "The Timing and Funding of Fedwire Funds Transfers.” Federal Reserve Bank of New York Economic Policy Review 6(2), 17-32.

McAndrews, James, Asani Sarkar, and Zhenyu Wang. 2008. "The Effect of the Term Auction Facility on the London Inter-Bank Offered Rate.” Federal Reserve Bank of New York, Staff Report no. 335.

Mees, Willem C. 1838. Proeve eener Geschiedenis van het Bankwezen in Nederland geduerende den Tijd der Republiek. W. Messcuert, Rotterdam.

Mistrulli, Paolo Emilio. 2011. "Assessing financial contagion in the interbank market: Maximum entropy versus observed interbank lending patterns.” Journal of Banking and Finance 35, 1114-1127.

Nogues-Marco, Pilar. 2011. "Competing Bimetallic Ratios: Amsterdam, London and Bullion Arbitrage in the $18^{\text {th }}$ Century." Universidad Carlos III de Madrid, Working Papers in Economic History, WP 11-03.

Polak, Menno. 1998. Historiografie en Economie van de 'Muntchaos', Deel II. NEHA, Amsterdam.

Pozsar, Zoltan, Tobias Adrian, Adam Ashcraft, and Hayley Boesky. 2010. "Shadow Banking." Staff Report no. 458, Federal Reserve Bank of New York.

Quinn, Stephen and William Roberds. 2010. "How Amsterdam got Fiat Money.” Federal Reserve Bank of Atlanta Working Paper 2010-17.

Sautijn Kluit, W.P. 1865. De Amsterdamsche Beurs in 1763 en 1773. W.H. Zeelt, Amsterdam. 
Schnabel, Isabel, and Hyun Song Shin, 2004. "Liquidity and Contagion: The Crisis of 1763." Journal of the European Economic Association 2(6): 929-968.

Schneider, Jürgen, Oskar Schwarzer, and Petra Schnelzer. 1991. Historische Statistik von Deutschland. Band XII: Statistik der Geld- und Wechselkurse in Deutschland und im Ostseeraum (18. Und 19. Jahrhundert). Scripta-Mercuratae-Verlag, St. Katharinen.

Singh, Manmohan and James Aitken. 2010. "The (sizable) Role of Rehypothecation in the Shadow Banking System.” IMF Working Paper 10/172.

Skalweit, Stephan. 1937. Die Berliner Wirtschaftskrise von 1763 und ihre Hintergründe. W. Kohlhammer, Stuttgart-Berlin.

Soetbeer, Adolf. 1855. Beiträge und Materialien zur Beurtheilung von Geld- und Bank-Fragen mit besonderer Rücksicht auf Hamburg. Herold'sche Buchhandlung, Hamburg.

Spooner, Frank C. 2002. Risks at Sea: Amsterdam insurance and maritime Europe, 1766-1780. Cambridge University Press.

Tooke, Thomas. 1838. A History of Prices and of the State of Circulation from 1793 to 1837, Vol. I. Longman, Orme, Brown, Green, and Longmans, London.

Upper, Christian. 2007. "Using counterfactual simulations to assess the contagion in interbank markets.” Bank for International Settlements, Working Paper no. 234.

Valukas, Anton R. 2010. “Report of Anton R. Valukas, Examiner,” Report, in re Lehman Brothers Holdings Inc., et al., Debtors.

Van Dillen, Johannes Gerard. 1922. "De Beurscrisis te Amsterdam in 1763.” Tijdschrift voor Geschiedenis.

Van Dillen, Johannes Gerard. 1925. Bronnen Tot de Geschiedenis der Wisselbanken. Martinus Nijhoff, The Hague.

Van Dillen, Johannes Gerard. 1931. “Effectenkoersen aan de Amsterdamsche Beurs 1723-1794.” Economisch-Historish Jaarboek, 17, 1-46.

Van Dillen, Johannes Gerard. 1934. "The Bank of Amsterdam.” In History of the Principal Public Banks, ed. Johannes Gerard van Dillen, 79-124. Martinus Nijhoff, The Hague.

Van Dillen, Johannes Gerard. 1964a. "Oprichting en Functie der Amsterdamse Wisselbank in de zeventiende Eeuw 1609-1686,” in J.G. van Dillen, ed. Mensen en Achtergronden, Studies uitgegeven ter gelegenheid van de tachtigste jaardag van de schrijver. J.B. Wolters, Groningen. 
Van Dillen, Johannes Gerard. 1964b. “Bloeitijd der Amsterdamse Wisselbank 1687-1781,” in J.G. van Dillen, ed. Mensen en Achtergronden, Studies uitgegeven ter gelegenheid van de tachtigste jaardag van de schrijver. J.B. Wolters, Groningen.

Wilson, Charles. 1941 (1966 reprint). Anglo-Dutch Commerce and Finance in the Eighteenth Century. Cambridge University Press. 
Appendix A: Additional tables. 
Table A1: Overview of Bank of Amsterdam transactions, January-July 1763

(units are thousands of bank florins unless otherwise indicated)

\begin{tabular}{|c|c|c|c|c|c|c|c|}
\hline Merchant bank (account $j$ ) & $\begin{array}{l}\text { Mean weekly } \\
\text { starting bal- } \\
\text { ance } \\
T^{-1} \sum_{t} B_{j t}\end{array}$ & $\begin{array}{c}\text { Number } \\
\text { debit } \\
\text { entries, } \\
\text { account } \\
j\end{array}$ & $\begin{array}{l}\text { Mean weekly } \\
\text { interaccount }^{61} \\
\quad \text { debits } \\
T^{-1} \sum_{t} \sum_{i=1}^{9} X_{i j t}\end{array}$ & $\begin{array}{l}\text { Mean coin } \\
\text { withdraw- } \\
\text { als } \\
T^{-1} \sum_{t} X_{10, j t}\end{array}$ & $\begin{array}{l}\text { Mean coin } \\
\text { deposits } \\
T^{-1} \sum_{t} X_{j, 10, t}\end{array}$ & $\begin{array}{c}\text { Mean total } \\
\text { debits } \\
T^{-1} \sum_{t} \sum_{i=1}^{10} X_{i j t}\end{array}$ & $\begin{array}{c}\text { Mean ratio } \\
\text { debits / } \\
\text { balances } \\
T^{-1} \sum_{t}\left(\sum_{i=1}^{10} X_{i j t}\right) / B_{j t}\end{array}$ \\
\hline Hope \& Compagnie & 439.3 & 2151 & 448.2 & 25.7 & 24.2 & 473.9 & 1.12 \\
\hline Andries Pels \& Zoonen & 359.7 & 1485 & 220.8 & 25.0 & 0.0 & 245.8 & 0.70 \\
\hline George Clifford \& Zoonen & 277.1 & 1819 & 368.9 & 23.4 & 1.9 & 392.3 & 1.49 \\
\hline Gebroeders de Neufville & 103.3 & 1395 & 239.3 & 2.0 & 0.4 & 241.3 & 2.69 \\
\hline Vernede \& Compagnie & 99.0 & 1216 & 179.2 & 0.4 & 1.4 & 179.5 & 2.75 \\
\hline $\begin{array}{l}\text { Raymond \& Theodoor de } \\
\text { Smeth }\end{array}$ & 77.7 & 799 & 153.8 & 10.8 & 0.0 & 164.5 & 2.57 \\
\hline Horneca Hogguer \& Co. & 69.7 & 987 & 134.0 & 12.8 & 1.0 & 146.7 & 2.51 \\
\hline $\begin{array}{l}\text { Charles \& Theophilus Caze- } \\
\text { nove }\end{array}$ & 68.7 & 1351 & 224.4 & 3.3 & 0.0 & 227.7 & 4.25 \\
\hline Total 8 large banks & $1,494.5$ & 11,191 & 1968.6 & 103.4 & 28.9 & 2071.7 & \\
\hline (Rest of the Bank accounts) & $21,686.0$ & & $1811.3^{62}$ & 114.0 & 150.5 & $1925.3^{63}$ & \\
\hline
\end{tabular}

\footnotetext{
61 "Interaccount" refers to transactions between private accounts that do not involve the flow of metal into or out of the Bank.

${ }^{62}$ Sum of transfers to eight most active accounts.

${ }^{63}$ Sum of coin withdrawals plus transfers to eight most active accounts.
} 


\section{Table A2: Overview of Bank of Amsterdam transactions, August 1763-January 1764}

(units are thousands of bank florins unless otherwise indicated)

\begin{tabular}{|c|c|c|c|c|c|c|c|}
\hline Merchant bank (account $j$ ) & $\begin{array}{l}\text { Mean weekly } \\
\text { starting bal- } \\
\text { ance } \\
T^{-1} \sum_{t} B_{j t}\end{array}$ & $\begin{array}{c}\text { Number } \\
\text { debit } \\
\text { entries, } \\
\text { account } \\
j\end{array}$ & $\begin{array}{l}\text { Mean weekly } \\
\text { interaccount }^{64} \\
\quad \text { debits } \\
T^{-1} \sum_{t} \sum_{i=1}^{9} X_{i j t}\end{array}$ & $\begin{array}{c}\text { Mean } \\
\text { metal }^{65} \\
\text { withdraw- }^{\text {als }} \\
T^{-1} \sum_{t} X_{10, j t}\end{array}$ & $\begin{array}{l}\text { Mean metal } \\
\quad \text { deposits } \\
T^{-1} \sum_{t} X_{j, 10, t}\end{array}$ & $\begin{array}{c}\text { Mean total } \\
\text { debits } \\
T^{-1} \sum_{t} \sum_{i=1}^{10} X_{i j t}\end{array}$ & $\begin{array}{c}\text { Mean ratio } \\
\text { debits / } \\
\text { balances } \\
T^{-1} \sum_{t}\left(\sum_{i=1}^{10} X_{i j t}\right) / B_{j t}\end{array}$ \\
\hline Hope \& Compagnie & 635.1 & 2069 & 341.4 & 0.0 & 12.1 & 341.4 & 0.55 \\
\hline Andries Pels \& Zoonen & 675.9 & 1342 & 201.0 & 2.5 & 27.3 & 203.5 & 0.31 \\
\hline George Clifford \& Zoonen & 354.6 & 1925 & 274.9 & 10.8 & 33.9 & 285.7 & 1.00 \\
\hline Vernede \& Compagnie & 67.4 & $825^{66}$ & 121.4 & 1.5 & 10.0 & 122.8 & 2.22 \\
\hline $\begin{array}{l}\text { Raymond \& Theodoor de } \\
\text { Smeth }\end{array}$ & 77.3 & 443 & 85.5 & 0.0 & 5.7 & 85.5 & 1.21 \\
\hline Horneca Hogguer \& Co. & 92.7 & 908 & 132.2 & 3.8 & 18.4 & 136.0 & 2.05 \\
\hline $\begin{array}{l}\text { Charles \& Theophilus Caze- } \\
\text { nove }\end{array}$ & 47.2 & 1257 & 172.8 & 0.5 & 34.0 & 173.3 & 8.85 \\
\hline Total 7 surviving banks & $1,950.2$ & 8,769 & 1329.2 & 37.4 & 112.6 & 1404.9 & \\
\hline (Rest of the Bank accounts) & $25,406.7$ & & $1059.9^{67}$ & 77.8 & 319.0 & $1137.8^{68}$ & \\
\hline
\end{tabular}

\footnotetext{
64 “Interaccount” refers to transactions between private accounts that do not involve the flow of metal into or out of the Bank.

65 "Metal" refers to transactions in either coin or bullion.

${ }^{66}$ Authors' estimate.

${ }^{67}$ Sum of transfers to eight most active accounts.

${ }^{68}$ Sum of metal withdrawals plus transfers to eight most active accounts.
} 


\section{Appendix B. Additional Analysis of Liquidity Flows}

This appendix provides additional perspectives on disruptions to liquidity flows stemming from the Neufville failure.

\section{Net additions of liquidity}

The data displayed in Figure 4 can be rearranged to show net contributions of liquidity by various groups of market participants: the three established players, the parvenus, and the rest of the Bank accounts. Net contribution of liquidity is defined as the excess of payments originated over payments received (excluding metal deposits and withdrawals).

Figure B1: Contributions of liquidity by source (weekly), 1763:1-1764:1

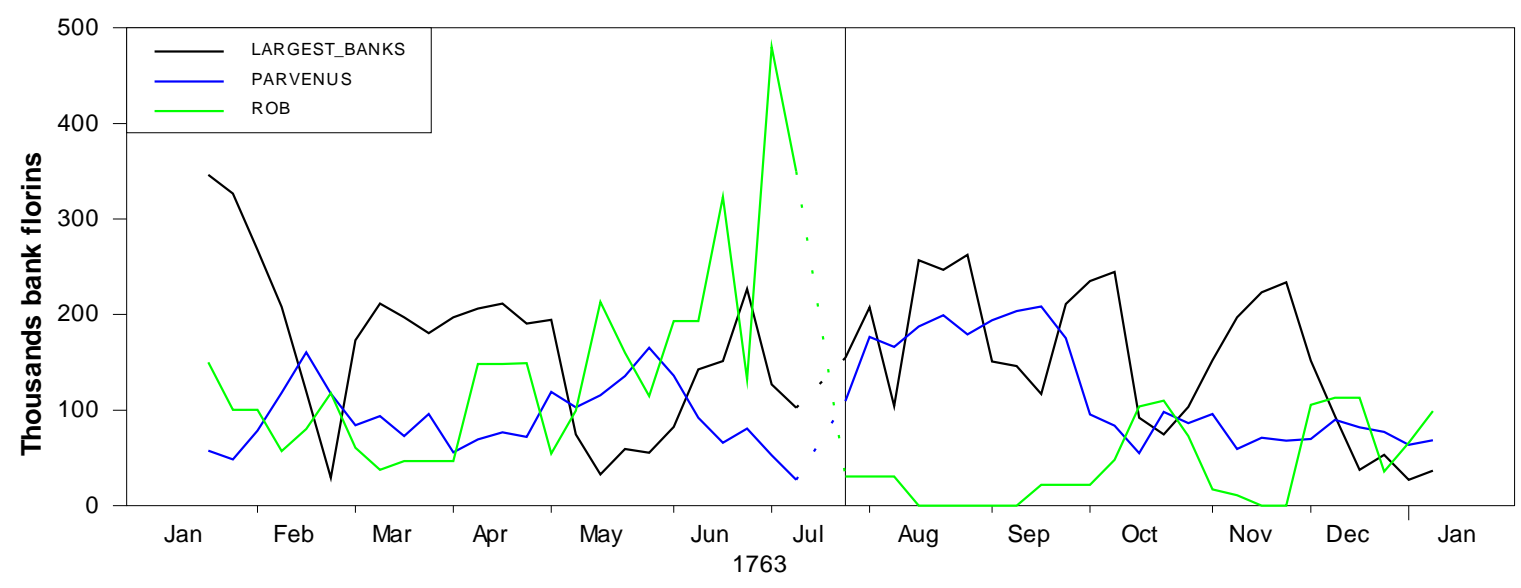

Source: Stadsarchief Amsterdam 5077.

Loss of the banks' funding liquidity is shown as a reduction in net liquidity contributions by nonbanks, from about 200,000 florins/ week to essentially zero in the wake of the Neufville failure.

Circulation of liquidity

Another perspective on liquidity flows is offered by the methodology developed in Bech, Chapman, and Garratt (2010) [BCG] to characterize the circulation of liquidity within a payment system. Following their analysis, we fit a simple Markov chain with states $\{1, \ldots, 9\}$ to the payments data $X_{i j t}$, where the states correspond to the eight large banks plus the ROB proxy account for 
the remaining Bank of Amsterdam account holders. An "adjacency matrix" is constructed for each data week $t$

$$
W_{i j t}=\frac{X_{i j t}}{\sum_{j} X_{i j t}} .
$$

The matrix $W_{t}$ is a stochastic matrix that indicates the probability of a florin moving from one Bank account to another. Following BCG, adjusted transition matrices $A_{t}$ for the Markov chain are then constructed from $W_{t}$, by taking diagonal elements of $A_{t}$ to be

$$
a_{i i t}=\theta_{i} \in[0,1]
$$

and off-diagonal elements as

$$
a_{i j t}=\left(1-\theta_{i}\right) w_{i j t}
$$

for $j \neq i$. BCG interpret the parameters $\theta_{i}$ as the tendency of liquidity to be retained in account $i$. Note also that from each $A_{t}$ one can calculate an associated steady-state probability distribution $\pi_{t}$ over states, using standard methods.

To calibrate the BCG model for, we first calculated the sample mean of the distribution of relative starting balances ("liquidity") $y_{i t}=B_{i t} /\left(\sum_{i} B_{i t}\right)$ over the nine accounts. We then chose $\theta_{i}$ to match this mean vector, by calculating time series of transition matrices $A$ and the sample mean of the corresponding time series of implied steady-state distributions $\pi_{t}{ }^{69}$ A three-parameter specification fits the empirical liquidity distribution very closely. Under this specification, for the first subsample (January-June 1763), $\theta_{i}=0$ for the parvenus (normalized value), $\theta_{i}=.54$ for the established banks, and $\theta_{i}=.96$ for the rest of the bank. In words, liquidity is returned instantaneously from the parvenus, at an intermediate pace from the established banks, and very slowly from the remaining accounts. When the BCG model is fitted to the second subsample (August 1763-January 1764), $\theta_{i}$ increases to .69 for the established banks, while remaining essentially

\footnotetext{
${ }^{69}$ Formal estimation is problematic since (1) as BCG note, their model is not identified if all components of $\theta$ are free, and (2) in our relatively sparse dataset there is little time variation in the sample distribution of liquidity.
} 
unchanged for the other accounts. From Tables A1-A2 this is most likely due to the actions of Hope and Pels, who deposited large amounts of coin while simultaneously reducing their payments outflow. This suggests that the established banks functioned as a liquidity "sink" over the second half of 1763 , relative to the pre-crisis period.

Table B1: Empirical and fitted distributions of liquidity

\begin{tabular}{|l|c|c|c|c|}
\hline & \multicolumn{4}{|c|}{ January-July 1763 } \\
\hline Firm & $\begin{array}{c}\text { Empirical liquidity } \\
\text { distribution, } \\
\text { in percent }\end{array}$ & $\begin{array}{c}\text { Fitted value } \\
\text { of } \theta\end{array}$ & $\begin{array}{c}\text { Implied distribu- } \\
\text { tion: naïve model } \\
(\theta=0) \text {, percent }\end{array}$ & $\begin{array}{c}\text { Implied distribu- } \\
\text { tion: fitted model, } \\
\text { percent }\end{array}$ \\
\hline Hope & 1.9 & .54 & 13.7 & 1.9 \\
\hline Pels & 1.6 & .54 & 6.9 & 1.0 \\
\hline Clifford & 1.2 & .54 & 11.3 & 1.6 \\
\hline Neufville & 0.4 & 0 & 3.8 & 0.5 \\
\hline Vernede & 0.4 & 0 & 2.7 & 0.3 \\
\hline Smeth & 0.3 & 0 & 2.4 & 0.3 \\
\hline Horneca Hogguer & 0.3 & 0 & 2.1 & 0.3 \\
\hline Cazenove & 0.2 & 0 & 3.5 & 0.5 \\
\hline Rest of the Bank & 93.6 & .96 & 53.5 & 93.6 \\
\hline
\end{tabular}

\begin{tabular}{|l|c|c|c|c|}
\hline & \multicolumn{4}{|c|}{ August 1763-January 1764 } \\
\hline Firm & $\begin{array}{c}\text { Empirical liquidity } \\
\text { distribution, } \\
\text { in percent }\end{array}$ & $\begin{array}{c}\text { Fitted value } \\
\text { of } \theta\end{array}$ & $\begin{array}{c}\text { Implied distribu- } \\
\text { tion: naïve model } \\
(\theta=0) \text {, percent }\end{array}$ & $\begin{array}{c}\text { Implied distribu- } \\
\text { tion: fitted model, } \\
\text { percent }\end{array}$ \\
\hline Hope & 2.3 & .69 & 15.5 & 2.5 \\
\hline Pels & 2.5 & .69 & 9.0 & 1.5 \\
\hline Clifford & 1.3 & .69 & 11.9 & 1.9 \\
\hline Vernede & 0.2 & 0 & 2.9 & 0.3 \\
\hline Smeth & 0.3 & 0 & 1.8 & 0.2 \\
\hline Horneca Hogguer & 0.3 & 0 & 3.1 & 0.3 \\
\hline Cazenove & 0.2 & 0 & 3.8 & 0.4 \\
\hline Rest of the Bank & 92.8 & .97 & 52.0 & 92.8 \\
\hline
\end{tabular}


Table B2. Pre-crisis leverage and relative shadow bank run

\begin{tabular}{|c|c|c|c|c|}
\hline & A & $\mathrm{B}$ & $\mathrm{C}$ & $\mathrm{C} / \mathrm{B}$ \\
\hline & $\begin{array}{r}\text { Pre-crisis } \\
\text { mean ratio of } \\
\text { average } \\
\text { weekly pay- } \\
\text { ments to av- } \\
\text { erage weekly } \\
\text { balances }\end{array}$ & $\begin{array}{r}\text { Balances } \\
\text { on July 29, } \\
\text { 1763, in bank } \\
\text { florin }\end{array}$ & $\begin{array}{l}\text { Cumulated } \\
\text { change in } \\
\text { balances ex- } \\
\text { cluding coin } \\
\text { and bullion } \\
\text { windows, in } \\
\text { bank florin }\end{array}$ & $\begin{array}{r}\text { Crisis ratio } \\
\text { of shadow } \\
\text { run } \\
\text { to starting } \\
\text { balance }\end{array}$ \\
\hline ndries Pels \& Zoonen & 0.7 & 476,508 & $-37,282$ & -0.078 \\
\hline Hope \& Compagnie & 1.12 & 792,850 & $-385,358$ & -0.486 \\
\hline seorge Clifford \& Zoonen & 1.49 & 446,975 & $-746,859$ & -1.671 \\
\hline Horneca Hogguer \& Co. & 2.51 & 117,716 & $-94,885$ & -0.806 \\
\hline Raymond \& Theodoor de Smeth & 2.57 & 150,936 & $-253,059$ & -1.677 \\
\hline Vernede \& Compagnie & 2.75 & 85,904 & $-228,588$ & -2.66 \\
\hline Charles \& Theophilus Cazenove & 4.25 & 122,366 & $-703,825$ & -5.752 \\
\hline
\end{tabular}




\section{Appendix C. Construction of payments data}

Data regarding the account activity of the eight merchant bankers at the Bank of Amsterdam are derived from the original, extant records kept at the Amsterdam Municipal Archive (Stadsarchief Amsterdam) inventory number 5077. These accounts allow us to construct a weekly matrix of gross flows between each banker, the other account holders (rest of the Bank, or ROB), and the Bank itself.

\section{A. Merchant Bankers}

For the fiscal year 1763, the bank account of each of the eight merchant bankers was photographed. The accounts were substantial. For example, Hope \& Co.’s account ran 39 folios during the second half of 1763. The ledger inventory numbers are 5077/ 440, 441 and 442 for 1763a (Jan-Jul); and 5077/443, 444 and 445 for 1763b (Aug-Jan 1764). To expedite processing, we limited our focus.

- We calculated the gross flows into and out of each account by week. This was expedited by the fact that the Bank calculated cumulative debts and cumulative credits every 5 transactions. The Bank only netted debits and credits when transferring a banker's balance to a new folio.

- We then examined each transfer payment and recorded those to or from another merchant banker. After repeating this for all eight bankers, we cross-referenced the transactions to double check our results and identify errors.

\section{B. Bank of Amsterdam}

To detail changes in the stock of bank money and how those changes occurred, we photographed and reconstructed two sets of accounts.

\section{Specie Kamer (“coin room” or master account)}

One set of accounts record the creation and destruction of bank florins. The creation of bank florins through the deposit of collateral/creation of receipts was recorded under the title of the bank officers receiving the coin. In 1763, these receivers were Willem van Housen (5077/441 and 444) and Hendrik Graauwhart (5077/442 and 445). All other transactions that altered the quantity of bank money were recorded in a type of master ac- 
count called the Specie Kamer (5077/441 and 444). It records 1) bank florin destruction such as withdrawals via receipt, fee payments, interest payments, loan repayments and open market sales and 2) non-receipt bank florin creation such as loans and open market purchases.

2. Collateral Book (Groetboeken van de Specie Kamer)

A different set of accounts (5077/1390) detail the flow of coins and bullion into and out of the Bank in the fiscal year 1763. This book records the coin surrendered to the Bank in order to create bank florins and a receipt, the coins repurchased from the Bank, and the interest paid to execute or rollover receipt options. The book also records bullion flows, but not bullion fineness.

\section{Rest of the Bank}

We calculated the Rest of the Bank as the remainder of flows into and out of the individual accounts unaccounted for by other merchant bankers or by the Bank of Amsterdam. 


\section{Appendix D. The bullion window}

On August 4, 1673, the AWB authorized a repo window for silver bullion (van Dillen 1925, 412). The bank set the minimum collateral amount at 10,000 bank florins. Depositors got a standard receipt at a 0.5 percent repurchase/renewal rate.

The bank scaled silver bullion's price by fineness. To see this, Table C1 standardizes the various fineness rates on a bank-florins-per-mark-pure-silver scale. We call this the bank price, for it is analogous to a coin's mint price. The differences being that the bank price delivered Bank (fiat) money of account instead of coins. Also, the Bank did not charge a fee to produce bank florins. Instead, it charged a fee to destroy them. The price scale gave customers an incentive to cast silver to a fineness of 11/12 'ths. Extant sources do not record the fineness of bullion actually received, so our analysis assumes silver bullion presented to the window had a fineness of 91.7 percent.

Table D1. Silver bullion's bank price

\begin{tabular}{|c|c|c|c|}
\hline \multicolumn{2}{|c|}{ Fineness } & $\begin{array}{c}\text { Bank Florins } \\
\text { per Mark }\end{array}$ & $\begin{array}{c}\text { Bank Florins } \\
\text { per Mark Pure Silver }\end{array}$ \\
\hline $11 / 12$ & $91.7 \%$ & 21 & 22.91 \\
\hline $10 / 12$ & $83.3 \%$ & 19 & 22.80 \\
\hline $9 / 12$ & $75.0 \%$ & 17 & 22.67 \\
\hline $8 / 12$ & $66.7 \%$ & 15 & 22.50 \\
\hline $7 / 12$ & $58.3 \%$ & 13 & 22.29 \\
\hline $6 / 12$ & $50.0 \%$ & 11 & 22 \\
\hline $5 / 12$ & $41.7 \%$ & 9 & 21.60 \\
\hline $4 / 12$ & $33.3 \%$ & 7 & 21 \\
\hline $3 / 12$ & $25 \%$ & 4.5 & 18 \\
\hline
\end{tabular}

Source: van Dillen (1925, 412). 
Those holding silver bullion had other ways to gain bank florins, so the new facility had to strike a balance between effectiveness and destabilization. It needed a price point that could help alleviate the liquidity crisis while not creating an incentive to avoid the minting of coins, or worse, the melting of existing coins. To check this, we will consider two alternative ways to convert bullion into bank florins through Dutch mints. One could mint bullion and then purchase bank florins on the agio (secondary) market. Or, one could mint bullion and then use the bank's repurchase facilities.

\section{A. Options to acquire liquidity: mint bullion}

\section{Mint bullion and buy bank florins}

The rate at which bullion can be converted (coined) into current money is called the mint price, and customers seek the highest mint price available. In 1763, most large silver coins in the Dutch Republic had a mint price of 25.1 current guilders per mark pure silver (Polak 1998). Denote the agio percent rate as $a$. Minting bullion and then selling the resulting coin on the agio market would produce the same bank florins as the bullion window if

$$
25.1 \times\left(\frac{1}{1+a}\right)=22.91 \text {, or } a=.0956
$$

So the bullion window would not disrupt minting incentives unless the agio was above 9.56 percent.

The exception to the common mint price was the Zeeland ryxdaalder. To promote its own mint business, the province of Zeeland set their price floor above that used by the rest of the Dutch Republic. Zeeland increased the legal value of their ryxdaalder (introduced in 1659 at 2.5 current guilders), to 2.55 in 1672, 2.6 in 1747, and 2.65 in 1762 (Polak 1998, 73). In turn, arbitrage caused the market price of Zeeland ryxdaalders throughout the Republic to follow (Polak 1998, 202). If the Zeeland ryxdaalder held its value in Amsterdam, then its mint price of 26.127 would outperform the bullion window for any agio up to 14 percent. 
2. Mint bullion and repo at the coin window

Some Dutch coins had repurchase ("repo") windows at the Bank, and the bank florin values the Bank assigned those coins meant that minting coins and then repoing them was always superior to the bullion window. To see this, Table C2 calculates the number of coins in a mint price, and then multiplies that number by the bank florins per coin the Bank offered. Again, people sought the highest "bank price" for their bullion. The ryxdaalder offered the most at 24.10 bank florins per mark pure silver, and that price exceeds the 22.91 offered bullion, so the bullion window did not alter long-term incentives to mint-and-repo.

Table D2. Specifics of Dutch coins with Bank repo windows

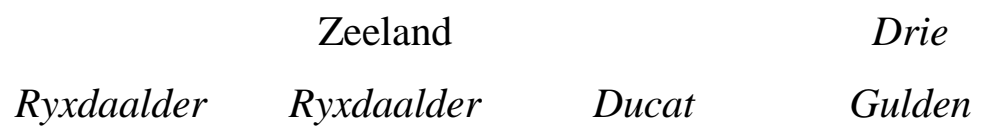

\section{Mint Price}

(current guilders per

25.1

26.127

25.1

25.1

mark fine silver)

Current Guilders

Per Coin

3

Coins per Mark

at Mint Price

9.86

7.97

Bank Florins

per Coin

2.4

3

\section{Bank Price}

\section{Bank Florins}

Per mark of fine silver

24.10

23.66

23.91

23.85

(via a mint)

We should note that the Zeeland ryxdaalder was particularly unattractive for mint-and-repo, for the substantial seigniorage the province took during minting meant that Zeeland ryx- 
daalders had an unfavorable bank price in Amsterdam, and we find no evidence of Zeeland ryxdaalders in the bank's vaults.

Finally, whether mint-and-buy or mint-and-repo offered the best deal depended on the market agio. The ryxdaalder bank price equals mint-and-sell when agio was 4.15 percent, so, for newly minted coins, the Bank's window offered a superior bank price to the secondary market when the agio was greater than 4.15 .

\section{B. Another option to acquire liquidity: sell bullion}

The bullion window at the AWB, however, could become attractive if people did not have time to mint bullion. In the short run (defined as not having time to mint bullion), one could sell bullion at its market price and then use the agio or use repo. This section shows that the bullion window could become the best alternative if the agio and the price of bullion were unusually low.

\section{Sell bullion and buy bank florins}

To be used at all, the bullion window had to improve on the secondary market, for resale was the fastest and most used way to gain bank florins. Define $\theta$ as the price to sell one mark of pure silver for current guilders. The bullion-market-and-agio-market value of silver is equal to the bullion window when:

$$
\theta\left(\frac{1}{1+a}\right)=22.91
$$

\section{Sell bullion and repo the coins}

The final path from bullion to bank florins was selling bullion for collateral acceptable to the Bank, and then repoing that collateral at the bank. To calculate the bank florins per mark for sell-and-repo, one needs

- $\theta$, the current price of a mark of bullion 
- $\quad$ the implicit agio per coin $(\bar{a})$.

The bank florins per mark bullion becomes $\theta \frac{1}{(1+\bar{a})}$.

For any $\theta$, customers seek the lowest implicit agio, but the implicit agio varied by coin. The implicit agio is the ratio of current guilders per coin in Table C3 over the bank florins per coin in Table C2.

\section{Table D3. Implicit agio by coin}

$\begin{array}{ccc}\text { Ryxdaalder } & \text { Ducat } & \text { Drie Gulden } \\ 2.5 & 3.15 & 3 \\ 2.4 & 3 & 2.85 \\ 4.1 \% & 5 \% & 5.2 \%\end{array}$

Of the Dutch coins, the lowest implicit agio was the ryxdaalder, so the bullion window offered the same bank florins as selling bullion for ryxdaalders (and then repoing them) when

$$
\theta \frac{1}{(1+\bar{a})}=22.91, \text { or } \theta=23.86
$$

So, if the price of bullion fell below 23.86, then the bullion window was superior to sell-andrepo. That bullion price threshold, however, assumes no money changing fees. It also assumes that the price of coins did not rise above their ordinance price-floors, so the threshold could easily have been higher depending on market conditions. 


\section{Acquiring liquidity through the bullion window}

We conclude that the bullion window had no effect on long-run incentives to mint bullion. It could, however, offer a dominant the bullion secondary market in the short-run channel if the price of silver bullion $(\theta)$ and the agio $(a)$ were low by historical standards.

The bullion window was superior to sell-and-repo if $\theta<23.86$, and it could also be superior to sell-and-buy for if the agio caused $\theta \frac{1}{(1+a)}<22.91$. To see the range of silver-agio pairings that could dominate, consider Figure C1. The price of silver $(\theta)$ is on the vertical axis, and the agio is on the horizontal. Any sell-bullion-and-buy-bank florins price combination is a point in this space. The "sell bullion-repo coins" threshold is in grey. The "sell bullion buy bank florins" threshold is in black. The area bounded by the thresholds, labeled "silver window," gives the set of market conditions that would make the silver window the best option for those seeking to convert silver bullion into bank florins.

While it is possible that the bullion window could dominate the bullion market, we have found no evidence that bullion prices were ever low enough. Only severe market frictions could have been brought this about. Instead, we conclude that the window was targeted at people seeking to make immediate use of silver bullion as collateral. 
Figure D1. Conditions for the bullion window's superiority

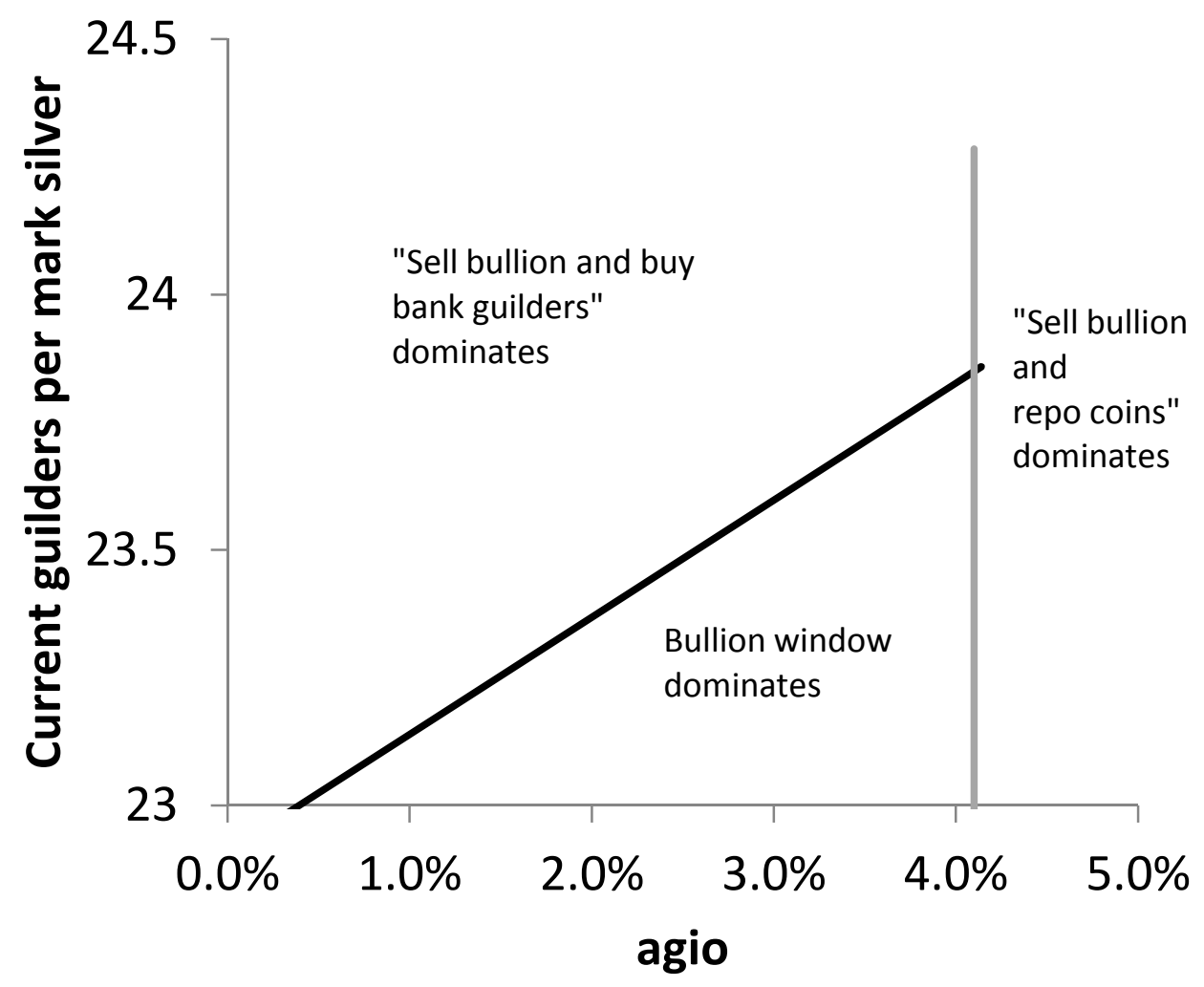




\section{Appendix E. Vaaten silver deposits}

In September 1763, a merchant named Benjamin Veijtel Ephraim used the bullion window to transform silver bullion into bank money payments to a few bankers. We consider this money as banker liquidity gained through the bullion window. This section explains what happened.

Benjamin Veijtel Ephraim was a member of a German Jewish family that supplied silver to the Prussian mints (Koser 1900). In installments on September 8, 10 and 13, Ephraim brought 364,864 bank florins worth of bullion to the bullion window (5077/1390, f. 30). The operation, however, was unique in a number of ways.

The Bank gave this bullion the title vaaten (barrel) silver, presumably because it arrived in barrels. All other bullion deposits were labeled baeren (bars). Although Ephraim took the receipts for the vaaten silver, he did not get the bank florins. Rather, the Bank created, and directly credited a special purpose account just for this money. The account was jointly held by three merchant bankers (Andries Pels \& Zoonen, George Clifford \& Zoonen, and Raymond \& Theodor de Smeth) and one potential banker (Harmen van de Poll).

No sooner had the money arrived than it was dispersed to the owners, a prominent bullion merchant, and Ephraim himself. Table E1 reconstructs these transactions and shows how we accounted for them.

Our interpretation of these events is that Ephraim owed these bankers money, and this was an acceptable way to pay them. We suspect this based on the approaches not taken. Ephraim could have had the funds credited to his own account, but then the bankers would have had to rely on him to transfer the funds to their account. The fact that a residual 16,000 went to Ephraim's account underscores that he got what was left.

Alternately, Ephraim could have given the silver to the bankers. That he did not sell the silver suggest that market prices were low and expected to recover. That he did not give the silver over as private collateral suggests that either market terms were less attractive than the bullion window or that the bankers preferred to let the Bank handle the collateral.

Finally, we know that Ephraim retained the receipts for the deposited silver, for he began repurchasing the vaaten silver starting on November 3 (5077/1390, f. 31; 5077/443, f. 141). Again, the 
bullion receipts had a relatively large haircut and high rate, so he had an incentive to unwind his repurchase agreement.

Table E1. The vaaten silver operation

\begin{tabular}{|c|c|c|c|c|c|}
\hline \multicolumn{6}{|c|}{ Bullion credits } \\
\hline to the joi & nt account of & & & & \\
\hline \multicolumn{2}{|c|}{$\begin{array}{l}\text { "Pels, Clifford, Smeth } \\
\text { and van de Poll" }\end{array}$} & \multicolumn{2}{|c|}{$\begin{array}{l}\text { Debits from } \\
\text { the joint account }\end{array}$} & \multirow{2}{*}{$\begin{array}{l}\text { To the account of } \\
\text { van de Poll }\end{array}$} & \multirow{2}{*}{$\begin{array}{l}\text { Treated as bul- } \\
\text { lion funding for } \\
\text { Rest of Bank }\end{array}$} \\
\hline Sept. 8 & $151,534.5$ & Sept. 9 & 20,000 & & \\
\hline & & & 20,000 & Smeth & Smeth \\
\hline \multirow{4}{*}{ Sept. 10} & \multirow{4}{*}{193,732} & \multirow{4}{*}{ Sept. 12} & $59,999.85$ & Pels & Pels \\
\hline & & & 58,000 & van de Poll & Rest of Bank \\
\hline & & & 48,000 & Clifford & Clifford \\
\hline & & & 70,000 & Moses Philip & Rest of Bank \\
\hline \multirow{4}{*}{ Sept. 13} & \multirow{4}{*}{$19,597.5$} & \multirow{4}{*}{ Sept. 14} & 60,000 & Smeth & Smeth \\
\hline & & & 16,000 & Benjamin Veijtel & \multirow[t]{2}{*}{ Rest of Bank } \\
\hline & & & & & \\
\hline & & & 12,700 & Pels & Pels \\
\hline Total & 364,864 & & $364,699.85$ & & \\
\hline
\end{tabular}




\section{Appendix F. Mint Activity}

In the monetary system of the Dutch Republic, a silver bullion price below 25.1 current guilders per mark pure silver would encourage minting. In 1763-4, there, was a great deal of minting. Figure F1 shows the production of silver coins at the Republic's six provincial mints from 1740 to 1798 . The series has two caveats. It is smoothed because mint report periods were irregular, so we cannot be more specific regarding when the surge began and ended. The series is also occasionally incomplete, so it is a minimum.

The spike in 1763-4 dwarfs previous years. The two year total of about 1 million marks translates into roughly 25 million current guilders. That flow is approximately the same size as the Bank of Amsterdam's stock of metal, and only 1 to 2 million of that production moved directly to the Bank.

In normal times, the dominant coin produced was the ryxdaalder: a coin used for international trade. Again, the ryxdaalder had a superior implicit agio than other Dutch coins (see Table D3). Zeeland Ryxdaalder production (for domestic use) is in grey, and its production clearly increased with the provincial price floor increases in 1747 and 1762.

The crisis, however, also brought a surge in the gulden production. The gulden had no repo window at the Bank and was not used for export, so evidently many people wanted coins to make current guilder payments in the domestic economy rather than payments inside the bank or for international trade. The mint numbers suggest that the Panic of 1763 particularly disrupted the domestic Dutch payment system. 
Figure F1. Mint production of silver coins, 1740 to 1789

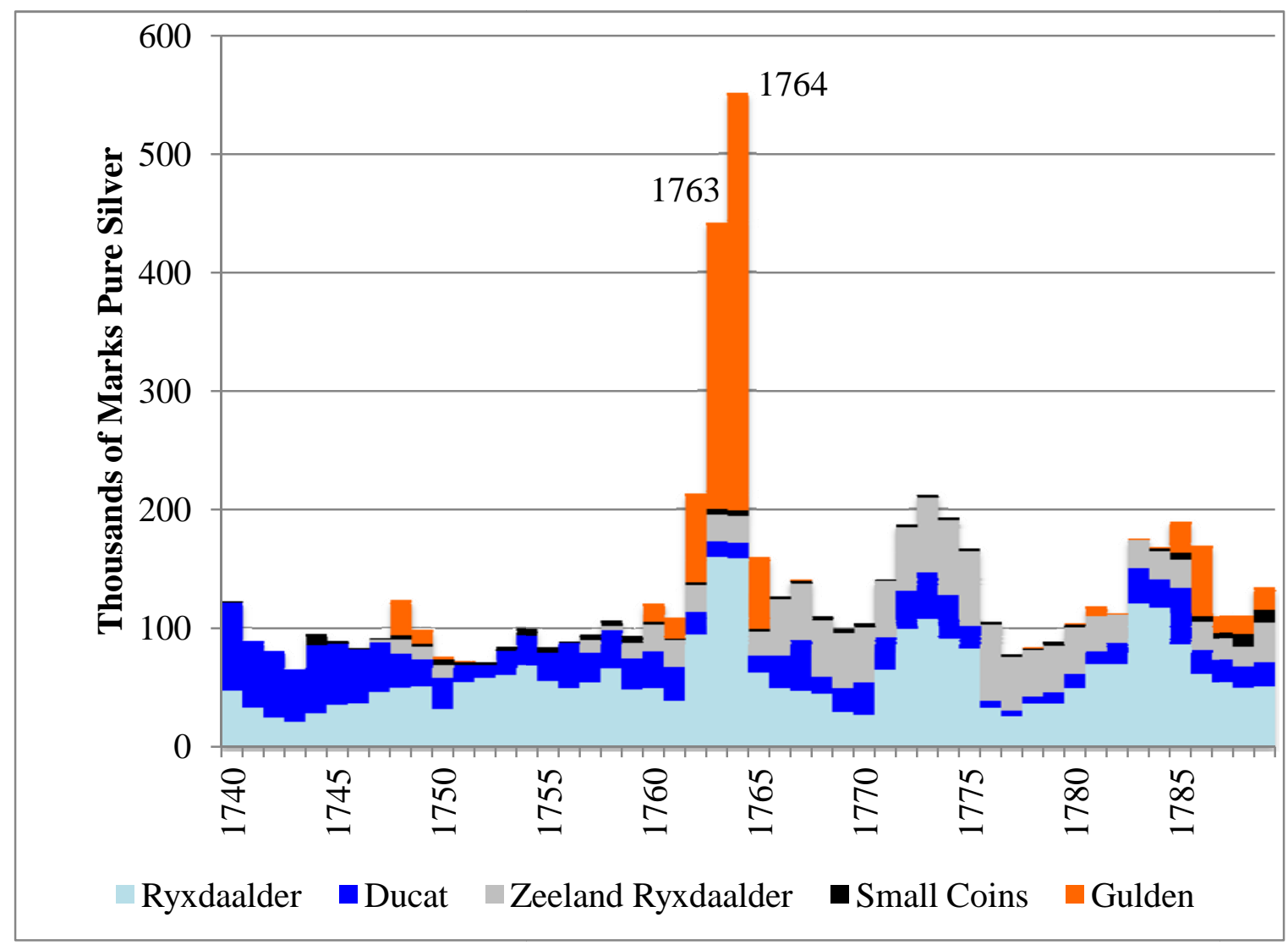

Source: Derived from Polak 1998. 


\section{Appendix G. Accounts of other bankers, July 1763-January 1764}

These are the balances and for bankers not pictured in the paper.

Figure G1. Weekly balances of Pels

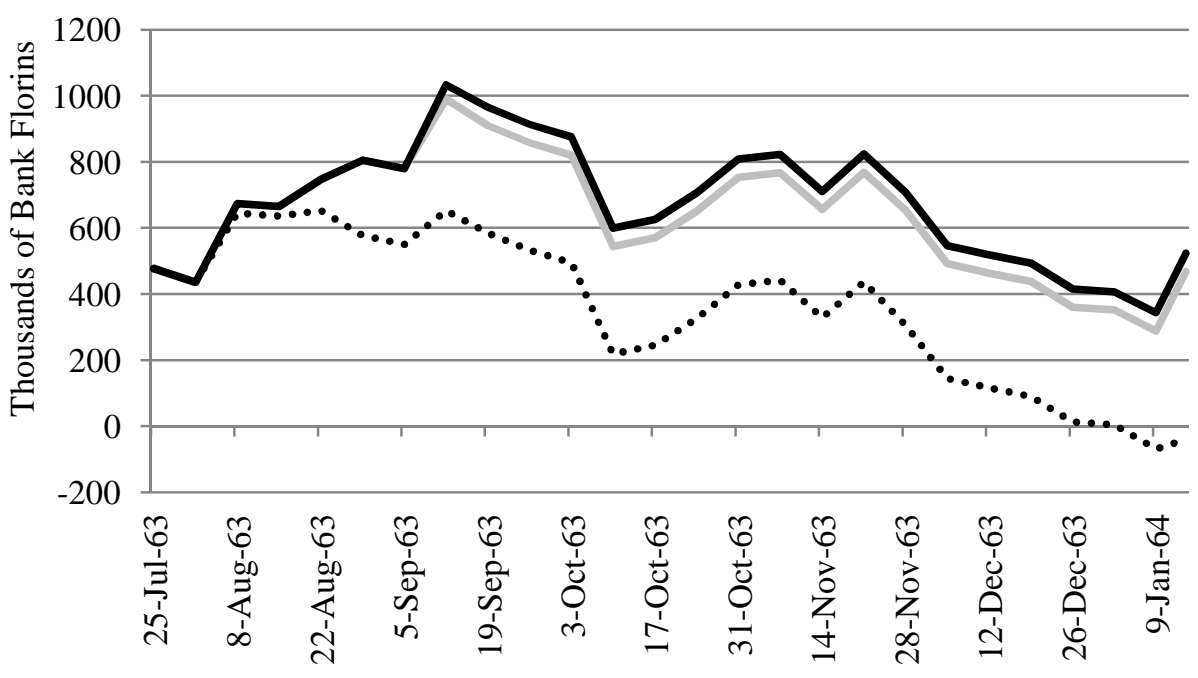

Without Bullion Window..... Without Coin Window $\longrightarrow$ Baseline

Figure G2. Weekly balances of Clifford

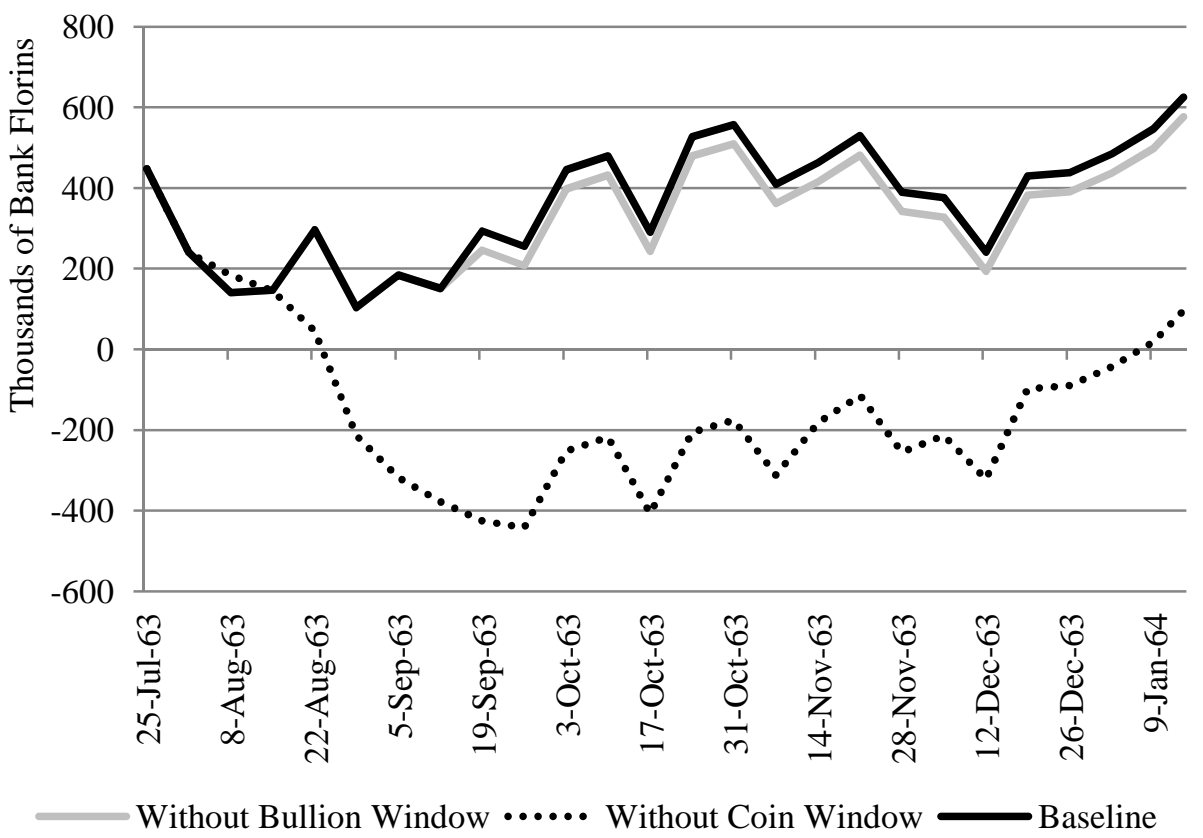


Figure G3. Weekly balances of Vernede

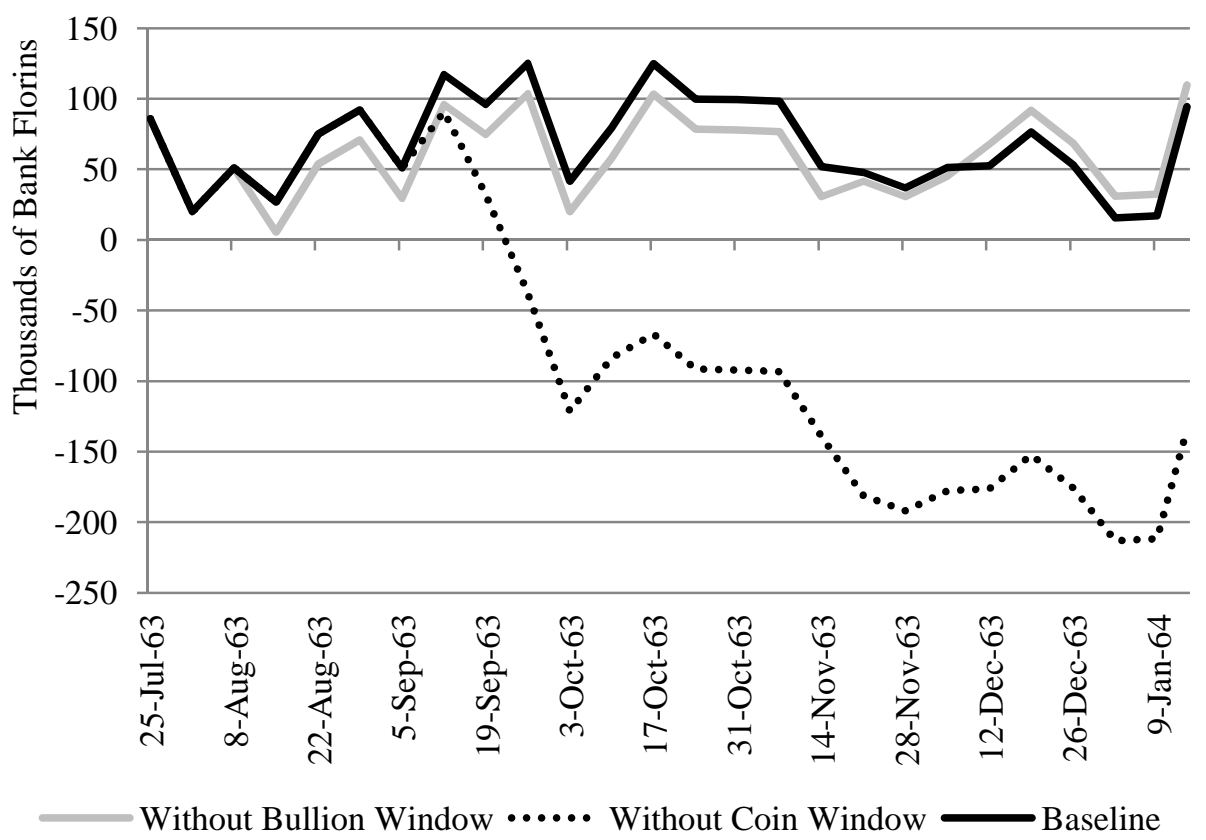




\section{Appendix H. Bank of Amsterdam Balance Sheet}

Table H1. Bank of Amsterdam Balance Sheet for Fiscal Year 1763,

by week in bank florins

\begin{tabular}{|c|c|c|c|c|c|c|}
\hline Date & & & ASSETS & & LIABILITIES & CAPITAL \\
\hline Start & Week & TOTAL & Metal & Loans & Accounts & \\
\hline 28-Jan-63 & 1 & $23,120,636$ & $22,893,372$ & 227,264 & $22,945,231$ & 175,405 \\
\hline 31-Jan-63 & 2 & $23,180,956$ & $22,953,692$ & 227,264 & $23,002,323$ & 178,633 \\
\hline 7-Feb-63 & 3 & $23,177,201$ & $22,949,937$ & 227,264 & $22,994,333$ & 182,868 \\
\hline 14-Feb-63 & 4 & $23,152,841$ & $22,925,577$ & 227,264 & $22,965,734$ & 187,107 \\
\hline 21-Feb-63 & 5 & $23,180,901$ & $22,953,637$ & 227,264 & $22,992,525$ & 188,376 \\
\hline 28-Feb-63 & 6 & $23,129,321$ & $22,902,057$ & 227,264 & $22,942,009$ & 187,311 \\
\hline 7-Mar-63 & 7 & $23,677,121$ & $23,449,857$ & 227,264 & $23,556,140$ & 120,981 \\
\hline 14-Mar-63 & 8 & $24,291,006$ & $24,063,742$ & 227,264 & $24,205,654$ & 85,352 \\
\hline 21-Mar-63 & 9 & $24,252,486$ & $23,925,222$ & 327,264 & $24,139,929$ & 112,557 \\
\hline 28-Mar-63 & 10 & $24,464,586$ & $24,037,322$ & 427,264 & $24,258,772$ & 205,813 \\
\hline 4-Apr-63 & 11 & $24,238,376$ & $23,811,112$ & 427,264 & $24,038,524$ & 199,851 \\
\hline 11-Apr-63 & 12 & $24,389,116$ & $23,961,852$ & 427,264 & $24,188,447$ & 200,669 \\
\hline 18-Apr-63 & 13 & $23,961,316$ & $23,734,052$ & 227,264 & $23,754,320$ & 206,996 \\
\hline 25-Apr-63 & 14 & $23,620,976$ & $23,393,712$ & 227,264 & $23,372,356$ & 248,620 \\
\hline 2-May-63 & 15 & $23,242,331$ & $23,015,067$ & 227,264 & $23,174,987$ & 67,345 \\
\hline 9-Мay-63 & 16 & $23,241,531$ & $23,014,267$ & 227,264 & $23,198,377$ & 43,154 \\
\hline 16-Мау-63 & 17 & $23,182,131$ & $22,954,867$ & 227,264 & $23,153,277$ & 28,854 \\
\hline 23-Мау-63 & 18 & $23,023,651$ & $22,796,387$ & 227,264 & $22,982,126$ & 41,525 \\
\hline 30-Мау-63 & 19 & $22,985,711$ & $22,758,447$ & 227,264 & $22,936,736$ & 48,976 \\
\hline 6-Jun-63 & 20 & 22,906,991 & $22,679,727$ & 227,264 & $22,704,553$ & 202,439 \\
\hline 13-Jun-63 & 21 & $22,691,791$ & $22,464,527$ & 227,264 & $22,645,234$ & 46,558 \\
\hline 20-Jun-63 & 22 & $22,377,951$ & $22,150,687$ & 227,264 & $22,329,660$ & 48,291 \\
\hline 27-Jun-63 & 23 & $22,193,311$ & $21,966,047$ & 227,264 & $22,224,267$ & $-30,956$ \\
\hline 4-Jul-63 & 24 & $22,068,651$ & $21,841,387$ & 227,264 & $22,314,777$ & $-246,126$ \\
\hline 11-Jul-63 & 25 & $22,176,156$ & $21,848,892$ & 327,264 & $22,298,864$ & $-122,708$ \\
\hline 18-Jul-63 & 26 & $22,295,163$ & $21,767,899$ & 527,264 & $22,244,207$ & 50,956 \\
\hline 29-Jul-63 & 27 & $22,295,163$ & $21,767,899$ & 527,264 & $22,344,207$ & $-49,044$ \\
\hline 1-Aug-63 & 28 & $22,422,388$ & $21,895,124$ & 527,264 & $22,660,145$ & $-237,757$ \\
\hline 8-Aug-63 & 29 & $22,826,928$ & $22,199,664$ & 627,264 & $22,940,267$ & $-113,338$ \\
\hline 15-Aug-63 & 30 & $23,361,975$ & $22,534,711$ & 827,264 & $23,414,273$ & $-52,298$ \\
\hline 22-Aug-63 & 31 & $23,917,410$ & $22,990,146$ & 927,264 & $24,024,037$ & $-106,626$ \\
\hline 29-Aug-63 & 32 & $24,804,943$ & $23,677,679$ & $1,127,264$ & $24,668,294$ & 136,649 \\
\hline 5-Sep-63 & 33 & $25,770,675$ & $24,643,411$ & $1,127,264$ & $25,438,106$ & 332,569 \\
\hline 12-Sep-63 & 34 & $26,521,899$ & $25,394,635$ & $1,127,264$ & $26,398,435$ & 123,464 \\
\hline 19-Sep-63 & 35 & $26,750,906$ & $25,623,642$ & $1,127,264$ & $26,681,862$ & 69,044 \\
\hline
\end{tabular}




$\begin{array}{rrrrrrr}\text { 26-Sep-63 } & 36 & 27,227,297 & 26,100,033 & 1,127,264 & 27,046,318 & 180,979 \\ \text { 3-Oct-63 } & 37 & 27,512,605 & 26,385,341 & 1,127,264 & 27,318,559 & 194,046 \\ \text { 10-Oct-63 } & 38 & 27,761,045 & 26,633,781 & 1,127,264 & 27,675,445 & 85,601 \\ \text { 17-Oct-63 } & 39 & 28,283,291 & 27,156,027 & 1,127,264 & 27,983,359 & 299,932 \\ \text { 24-Oct-63 } & 40 & 28,742,173 & 27,614,909 & 1,127,264 & 28,590,493 & 151,680 \\ \text { 31-Oct-63 } & 41 & 29,268,410 & 28,141,146 & 1,127,264 & 28,906,700 & 361,710 \\ \text { 7-Nov-63 } & 42 & 29,568,851 & 28,441,587 & 1,127,264 & 29,466,072 & 102,779 \\ \text { 14-Nov-63 } & 43 & 30,010,488 & 28,883,224 & 1,127,264 & 29,883,099 & 127,389 \\ \text { 21-Nov-63 } & 44 & 29,945,180 & 29,717,916 & 227,264 & 29,731,910 & 213,270 \\ \text { 28-Nov-63 } & 45 & 29,995,039 & 29,767,775 & 227,264 & 29,860,840 & 134,199 \\ \text { 5-Dec-63 } & 46 & 30,249,001 & 30,021,737 & 227,264 & 30,099,279 & 149,722 \\ \text { 12-Dec-63 } & 47 & 30,326,299 & 30,099,035 & 227,264 & 30,198,588 & 127,711 \\ \text { 19-Dec-63 } & 48 & 30,490,984 & 30,263,720 & 227,264 & 30,350,896 & 140,088 \\ \text { 26-Dec-63 } & 49 & 30,580,639 & 30,353,375 & 227,264 & 30,462,793 & 117,846 \\ \text { 2-Jan-64 } & 50 & 30,695,547 & 30,468,282 & 227,264 & 30,539,826 & 155,720 \\ \text { 9-Jan-64 } & 51 & 30,793,889 & 30,566,625 & 227,264 & 30,649,858 & 144,031 \\ \text { 16-Jan-64 } & 52 & 31,085,138 & 30,857,874 & 227,264 & 30,966,847 & 118,291\end{array}$


Table H2. Bank of Amsterdam Metal Stock in FY 1763,

\section{by week in bank florins}

\begin{tabular}{|c|c|c|c|c|c|c|}
\hline \multirow[b]{3}{*}{ Week } & \multicolumn{5}{|c|}{ Under Receipt } & \multirow{2}{*}{$\begin{array}{r}\text { Unencumbered } \\
\text { Reserves }\end{array}$} \\
\hline & & COINS & & & BULLION & \\
\hline & TOTAL & Dutch & Dollars & Gold & & \\
\hline 1 & $22,893,372$ & $1,132,420$ & $21,225,600$ & 61,380 & 0 & 473,972 \\
\hline 2 & $22,953,692$ & $1,175,140$ & $21,243,200$ & 61,380 & 0 & 473,972 \\
\hline 3 & $22,949,937$ & $1,197,785$ & $21,216,800$ & 61,380 & 0 & 473,972 \\
\hline 4 & $22,925,577$ & $1,166,825$ & $21,223,400$ & 61,380 & 0 & 473,972 \\
\hline 5 & $22,953,637$ & $1,203,245$ & $21,201,400$ & 75,020 & 0 & 473,972 \\
\hline 6 & $22,902,057$ & $1,239,665$ & $21,113,400$ & 75,020 & 0 & 473,972 \\
\hline 7 & $23,449,857$ & $1,264,745$ & $21,595,200$ & 115,940 & 0 & 473,972 \\
\hline 8 & $24,063,742$ & $1,271,430$ & $22,202,400$ & 115,940 & 0 & 473,972 \\
\hline 9 & $23,925,222$ & $1,267,110$ & $22,068,200$ & 115,940 & 0 & 473,972 \\
\hline 10 & $24,037,322$ & $1,188,030$ & $22,266,200$ & 109,120 & 0 & 473,972 \\
\hline 11 & $23,811,112$ & $1,072,040$ & $22,162,800$ & 102,300 & 0 & 473,972 \\
\hline 12 & $23,961,852$ & $1,025,000$ & $22,367,400$ & 95,480 & 0 & 473,972 \\
\hline 13 & $23,734,052$ & 862,980 & $22,294,800$ & 102,300 & 0 & 473,972 \\
\hline 14 & $23,393,712$ & 789,060 & $22,035,200$ & 95,480 & 0 & 473,972 \\
\hline 15 & $23,015,067$ & 715,620 & $21,905,400$ & 95,480 & 0 & 298,567 \\
\hline 16 & $23,014,267$ & 673,020 & $21,947,200$ & 95,480 & 0 & 298,567 \\
\hline 17 & $22,954,867$ & 673,020 & $21,887,800$ & 95,480 & 0 & 298,567 \\
\hline 18 & $22,796,387$ & 644,340 & $21,758,000$ & 95,480 & 0 & 298,567 \\
\hline 19 & $22,758,447$ & 618,060 & $21,766,800$ & 75,020 & 0 & 298,567 \\
\hline 20 & $22,679,727$ & 625,140 & $21,681,000$ & 75,020 & 0 & 298,567 \\
\hline 21 & $22,464,527$ & 614,100 & $21,463,200$ & 88,660 & 0 & 298,567 \\
\hline 22 & $22,150,687$ & 639,060 & $21,124,400$ & 88,660 & 0 & 298,567 \\
\hline 23 & $21,966,047$ & 683,220 & $20,895,600$ & 88,660 & 0 & 298,567 \\
\hline 24 & $21,841,387$ & 684,180 & $20,776,800$ & 81,840 & 0 & 298,567 \\
\hline 25 & $21,848,892$ & 665,065 & $20,796,600$ & 88,660 & 0 & 298,567 \\
\hline 26 & $21,767,899$ & 662,185 & $20,721,800$ & 95,480 & 0 & 288,434 \\
\hline 27 & $21,767,899$ & 662,185 & $20,721,800$ & 95,480 & 0 & 288,434 \\
\hline 28 & $21,895,124$ & 710,210 & $20,801,000$ & 95,480 & 0 & 288,434 \\
\hline 29 & $22,199,664$ & 751,100 & $20,807,600$ & 278,665 & 73,866 & 288,434 \\
\hline 30 & $22,534,711$ & 755,195 & $21,058,400$ & 253,790 & 178,893 & 288,434 \\
\hline 31 & $22,990,146$ & 758,110 & $21,423,600$ & 253,790 & 266,213 & 288,434 \\
\hline 32 & $23,677,679$ & 764,325 & 21,881,200 & 301,530 & 442,191 & 288,434 \\
\hline 33 & $24,643,411$ & 769,155 & $22,660,000$ & 328,590 & 597,232 & 288,434 \\
\hline 34 & $25,394,635$ & 804,185 & $23,009,800$ & 336,053 & 956,164 & 288,434 \\
\hline 35 & $25,623,642$ & 825,655 & $23,097,800$ & 336,053 & $1,075,701$ & 288,434 \\
\hline 36 & $26,100,033$ & 839,215 & $23,485,000$ & 336,053 & $1,151,332$ & 288,434 \\
\hline 37 & $26,385,341$ & 887,095 & $23,643,400$ & 315,593 & $1,250,820$ & 288,434 \\
\hline 38 & $26,633,781$ & 940,470 & $23,889,800$ & 206,473 & $1,308,605$ & 288,434 \\
\hline
\end{tabular}




$\begin{array}{llrllll}39 & 27,156,027 & 953,940 & 24,343,000 & 199,653 & 1,371,001 & 288,434 \\ 40 & 27,614,909 & 1,088,465 & 24,602,600 & 199,653 & 1,435,758 & 288,434 \\ 41 & 28,141,146 & 1,158,955 & 25,000,800 & 199,653 & 1,493,305 & 288,434 \\ 42 & 28,441,587 & 1,200,185 & 25,275,800 & 199,653 & 1,477,516 & 288,434 \\ 43 & 28,883,224 & 1,226,795 & 25,680,600 & 199,653 & 1,487,743 & 288,434 \\ 44 & 29,717,916 & 1,329,270 & 26,408,800 & 206,473 & 1,484,940 & 288,434 \\ 45 & 29,767,775 & 1,336,640 & 26,492,400 & 206,473 & 1,443,829 & 288,434 \\ 46 & 30,021,737 & 1,424,715 & 26,622,200 & 249,593 & 1,436,796 & 288,434 \\ 47 & 30,099,035 & 1,517,575 & 26,666,880 & 249,593 & 1,376,554 & 288,434 \\ 48 & 30,263,720 & 1,629,085 & 26,774,680 & 239,643 & 1,331,879 & 288,434 \\ 49 & 30,353,375 & 1,717,095 & 26,801,080 & 234,668 & 1,312,099 & 288,434 \\ 50 & 30,468,282 & 1,852,570 & 26,831,880 & 214,208 & 1,281,191 & 288,434 \\ 51 & 30,566,625 & 1,939,370 & 26,853,880 & 194,308 & 1,290,634 & 288,434 \\ 52 & 30,857,874 & 1,913,585 & 27,161,880 & 177,538 & 1,325,315 & 279,556\end{array}$




\section{Appendix I. Implicit Bill Market Yields}

London was Amsterdam's most integrated international exchange partner (Neal 1990). Average exchange rates in Amsterdam weaken (Table C7), but the full cost of initiating acceptance finance depended on the rate that the London counterparty used to return the principal obligation to Amsterdam. Table C7 gives the hypothetical round trip $\operatorname{cost}^{70}$ of a four month loan (2 months out, 2 months back) using (1) a naïve ex ante assumption that the latest London rate available in Amsterdam would pertain at "re-exchange" "71 and (2) using an ex post assumption of the actual London rate two months later. Expected borrowing costs rose to over 10 percent, and realized rates were higher still as London adjusted to the liquidity crisis in Amsterdam. Privately supplied liquidity, when it was available, became extremely expensive.

Table C7. Average exchange rates for Amsterdam on London

$\begin{array}{rrrr} & \begin{array}{r}\text { Schellingen Banco/ } \\ \text { English Pound, } \\ \text { 2 Month Bills }\end{array} & \begin{array}{r}\text { Ex Ante } \\ \text { Re-exchange Rate, } \\ \text { Annualized }\end{array} & \begin{array}{r}\text { Ex Post } \\ \text { Re-exchange Rate, } \\ \text { Annualized }\end{array} \\ \text { January 1763 } & 34.50 & 4.2 \% & 4.2 \% \\ \text { Through July } & 34.26 & 6.6 \% & 12.3 \% \\ \text { August } & 33.79 & 10.9 \% & 19.7 \% \\ \text { September } & 34.65 & 6.6 \% & 11.9 \% \\ \text { October } & 34.82 & 8.7 \% & 10.3 \% \\ \text { November } & 35.13 & 7.4 \% & 11.6 \% \\ \text { December } & 35.79 & 1.9 \% & 6.7 \% \\ \text { January 1764 } & 35.88 & 4.8 \% & 4.4 \% \\ \text { February } & 36.02 & 4.7 \% & 4.1 \% \\ \text { March } & & & \end{array}$

Sources: Amsterdam rates from de Jong-Keesing 1939, 168; London rates from the Course of the Exchange.

\footnotetext{
${ }^{70}$ Under the assumption that a lender of funds viewed as credible the sequence of actions in Table 2.

${ }^{71}$ I.e., the drawing of a bill by the London drawee on the original (Amsterdam) drawer (i.e., borrower).
} 


\section{Appendix J. Agio series}

Figure J1 reports select daily agios (premium on Bank over current money) for 1763 from three sources.

Figure J1. Select Daily Agios in 1763

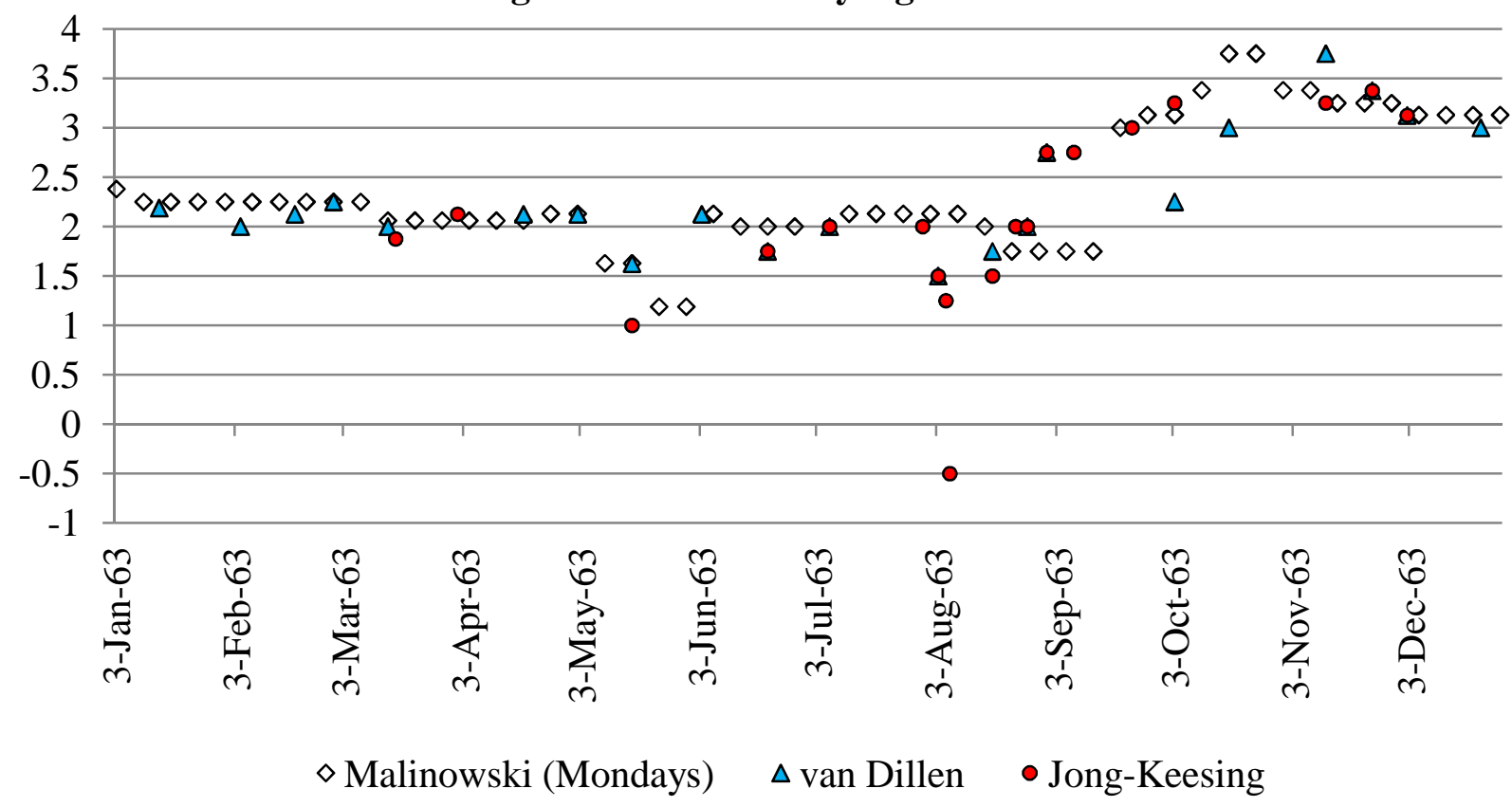

Sources: Malinowski (2011), van Dillen (1931, 34); de Jong-Keesing (1939, 165). 